\title{
Extraction and Use of Greywacke in Ancient Egypt
}

\author{
Ahmed Ibrahim Othman ${ }^{1}$ \\ Lecturer - Tourism Guidance Department \\ Hotel Management and Restoration Institute, Abu Qir.
}

\section{Introduction}

The Quseir - Qift road was the only practical route in the Central Easter Desert as it was the shortest and easiest road from the Nile Valley to the Red Sea, in addition to the richness of the Bekhen stone quarries and the gold mines. Therefore, it was the preferred road by the merchants, quarrymen and miners.

The Bekhen stone quarries of Wadi Hammamat forms an archaeological cluster of inscriptions, unfinished manufactures, settlements, workshops and remaining tools. It seems clear that the state was responsible for the Bekhen stone exploitation, given the vast amount of resources that had to be invested in the organization of a quarrying expedition. Unlike the other marginal areas, the officials leading the missions to Wadi Hammamat show different affiliations in terms of administrative branches. This is probably because Bekhen stone procurement was not the responsibility of the treasury, but these expeditions were entrusted to separate competent officials, graded in a specific hierarchy, forming well - organized missions with different workers for different duties and established wages and functionaries in charge of the administrative tasks.

The greywacke quarries were not constantly or intensively exploited. The fact that the stone was used in private or royal statuary and not as a building stone could have caused its demand to be less than that of other materials such as granite, limestone or sandstone.

Inscriptions indicated the time lapse between expeditions suggesting that this stone was only quarried when it was needed, which was not on a regular basis. However, the fact that the quarries were exploited over all the pharaonic periods makes it hard to determine the intensity of these activities, the inscriptions represent the base in creating a chronological sequence of Egyptian activities in the area.

Although inscriptions are not always eloquent about these matters, it seems clear that the missions had to bring tools, supplies and other materials to the wadi and store them during the work. As for the administrative buildings where duties should have been carried out, they were found in other areas and the fact that the modern road follows the same route that the ancient one does, is not helping in terms of preservation of archaeological remains. ${ }^{2}$ 


\section{Greywacke in the Ancient Egyptian Texts ${ }^{3}$}

Finding stone classifications in ancient written records is difficult, although there is a consensus that greywacke was known as the bekhen (bxn) stone, from at least the Middle Kingdom onwards, with the topographic term "mountain of bekhen" emerging by the New Kingdom. ${ }^{4}$

This stone used to be extracted mainly from Wadi Hammamat, the wadi represented in Turin Papyrus and referred to in the ancient times as wadi

$\lessdot \square$ ○ $\min 5$

\begin{tabular}{|c|c|c|c|}
\hline & Document & Date & Text \\
\hline 1 & $\begin{array}{l}\text { Limestone stela of } \\
\text { Bxn), preserved in } \\
\text { the Louvre } \\
\text { Museum. }\end{array}$ & $\begin{array}{c}12^{\text {th }} \text { Dynasty, } \\
\text { Middle } \\
\text { Kingdom. }\end{array}$ & $\begin{array}{l}\text { The deceased prays to be buried in } \\
\text { The tomb of Bekhenw Mountain (Wadi Hammamat). }\end{array}$ \\
\hline 2 & $\begin{array}{l}\text { Rock inscription of } \\
\text { wy), overseer of } \\
\text { the store room of } \\
\text { the controller of } \\
\text { works. }^{7}\end{array}$ & $\begin{array}{c}\text { The } 14^{\text {th }} \text { year, } \\
4^{\text {th }} \text { month of } \\
\text { the first } \\
\text { season, day } \\
16 \text { of } \\
\text { Senwsert III - } \\
12^{\text {th }} \text { Dynasty, } \\
\text { Middle } \\
\text { Kingdom. }\end{array}$ & $\begin{array}{l}\text { back some Bekhen stone and left there a record of } \\
\text { his work: "His majesty commanded that I should be } \\
\text { dispatched to } \\
\text { bring a monument which his majesty had } \\
\text { commanded to be made for the god Hry S .f, Lord of } \\
\text { Heracleopolis for the sake of the life of the king of } \\
\text { upper and lower Egypt, Senwsert III, living forever } \\
\text { and ever } \\
\text { m inr nfr } n \text { bxnw, } \\
\text { monuments of a beautiful block of Bekhenw" }\end{array}$ \\
\hline 3 & $\begin{array}{l}\text { Broken stela of a } \\
\text { real acquaintance } \\
\text { of the king } \\
\text { Amenemhat III } \\
\text { whose name is } \\
\text { missing. }\end{array}$ & $\begin{array}{l}\text { Amn-em-hat } \\
\text { III }-12^{\text {th }} \\
\text { Dynasty, } \\
\text { Middle } \\
\text { Kingdom. }\end{array}$ & $\begin{array}{l}\text { The text reads: } \\
\mathrm{m} \text { inr nfr } \mathrm{n} \text { bxnw } \\
\text { Of the beautiful stone of Bekhenw }\end{array}$ \\
\hline 4 & $\begin{array}{l}\text { Rock inscription of } \\
\text { Senwsret ( } \\
\text { overseer of half of }\end{array}$ & $\begin{array}{l}19^{\text {th }} \text { year, } \\
\text { first month of } \\
\text { second } \\
\text { season, day }\end{array}$ & $\begin{array}{l}\text { The official was sent by the king to remove Bekhen } \\
\text { stone for building purposes in the locality called } \\
\text { "Ankh Amenemhat (III)" located in the region of } \\
\text { Hawara where the pyramid of the king is situated, } \\
\text { and the building should be the king's pyramid temple }\end{array}$ \\
\hline
\end{tabular}




\begin{tabular}{|c|c|c|c|}
\hline & the Quarrymen. ${ }^{9}$ & $\begin{array}{c}15 \text { of } \\
\text { Amenemhat } \\
\text { III - } 12^{\text {th }} \\
\text { Dynasty, } \\
\text { Middle } \\
\text { Kingdom. }\end{array}$ & $\begin{array}{l}\text { at Hawara. } \\
\text { His Majesty sent to bring for himself monuments } \\
\text { from the valley of "Ra-Henew" of beautiful stone of } \\
\text { Bekhenw, as far as Ankh Amen - em - hat III, living } \\
\text { forever. }\end{array}$ \\
\hline 5 & $\begin{array}{l}\text { Model of a temple } \\
\text { of Heliopolis of } \\
\text { Sety I - Brooklyn } \\
\text { Museum. }{ }^{10}\end{array}$ & $\begin{array}{c}19^{\text {th }} \text { Dynasty, } \\
\text { New } \\
\text { Kingdom. }\end{array}$ & $\begin{array}{l}\text { txnwy m bxnw smn m iwnwAxt nt pt BAw iwnw } \\
\text { Ha n mA.w } \\
\text { He made two obelisks of Bekhenw stone, established } \\
\text { in Heliopolis, the horizon of heaven; the souls of } \\
\text { Heliopolis exult at seeing them. }\end{array}$ \\
\hline 6 & $\begin{array}{l}\text { Stela of } \\
\text { Judge of the royal } \\
\text { scribe and great } \\
\text { overseer of }\end{array}$ & $\begin{array}{c}\text { Reign of } \\
\text { Ramses II, } \\
19^{\text {th }} \text { Dynasty, } \\
\text { New } \\
\text { Kingdom. }\end{array}$ & $\begin{array}{l}\text { Wp nsw r Dw bxn r in n mnw n Hm .f } \\
\text { A Royal mission to the mountain of Bekhen to bring } \\
\text { monuments for his majesty. }\end{array}$ \\
\hline
\end{tabular}




\begin{tabular}{|c|c|c|c|}
\hline & $\begin{array}{l}\text { soldiers of the lord } \\
\text { of Upper and } \\
\text { Lower Egypt. }\end{array}$ & & \\
\hline 7 & $\begin{array}{l}\text { Small broken } \\
\text { obelisk - Borely } \\
\text { Museum, } \\
\text { Marseilles. }\end{array}$ & $\begin{array}{c}\text { Temple of } \\
\text { king Ramses } \\
\text { II at Tanis, } \\
19^{\text {th }} \text { Dynasty, } \\
\text { New } \\
\text { Kingdom. }\end{array}$ & $\begin{array}{l}\text { The fragmentary text seems to indicate that the } \\
\text { monument was erected by the king (to his father) } \\
\text { Hr irt } \mathrm{n} \text {.f txn } \mathrm{n} \text { bxn smn ..... } \\
\text { "Horus", he has made for him (The God) an obelisk } \\
\text { of Bekhen - stone and has established (it)......." }\end{array}$ \\
\hline 8 & $\begin{array}{l}\text { Turin Mines } \\
\text { Papyrus. }\end{array}$ & $\begin{array}{c}\text { Reign of } \\
\text { Ramses IV, } \\
20^{\text {th }} \text { Dynasty, } \\
\text { New } \\
\text { Kingdom. }\end{array}$ & $\begin{array}{l}\text { This fragmentary document describes the stone } \\
\text { quarrying in the Wadi Hammamat } \\
\text { Bxny r gmyt m pA Dw n bxny } \\
\text { "Bekheny stone which is found in the mountain of } \\
\text { Bekheny". } \\
\text { "The king, Life, Health, Strength, ordered the great } \\
\text { quarrymen to bring the list to him of Bekheney } \\
\text { stone". } \\
\text { reads: } \\
\text { (2) } \\
\text { bAkw }\end{array}$ \\
\hline
\end{tabular}




\begin{tabular}{|c|c|c|c|}
\hline & & & $\begin{array}{l}\text { Work up gold (extract it) till the end of the mountain } \\
\text { of Bekhen. }\end{array}$ \\
\hline 9 & Stela ${ }^{14}$ & $\begin{array}{l}\text { Second year, } \\
\text { second month } \\
\text { of first } \\
\text { season of } \\
\text { Ramses IV - } \\
20^{\text {th }} \text { Dynasty, } \\
\text { New } \\
\text { Kingdom. }\end{array}$ & $\begin{array}{l}\text { The text contains a reference to a personal visit of } \\
\text { the king to the Wadi. The text states that his majesty } \\
\text { ordered his officials to make a record of the visit, on } \\
\text { the stela, which is referred to as: } \\
\text { Mnw pn n st nHH m Dw pn n bxn m hAw tA nTr } \\
\text { This monument of the place of eternity in this } \\
\text { mountain of Bekhen, near God's land. }\end{array}$ \\
\hline 10 & Stela. ${ }^{15}$ & $\begin{array}{c}3^{\text {rd }} \text { year, } \\
\text { second month } \\
\text { of third } \\
\text { season, day } \\
27 \text { of Ramses } \\
\text { IV, } 20^{\text {th }} \\
\text { Dynasty, } \\
\text { New } \\
\text { Kingdom. }\end{array}$ & $\begin{array}{l}\text { This monument contains an account of a great } \\
\text { expedition to the Wadi. } \\
\text { In lines } 11 \text { and 12, The king commands two scribes } \\
\text { (Ra msw aSA Hb) and } \\
\text { The text reads: } \\
\text { To search the (wepew) } \\
\text { mountain of Bekhen. } \\
\text { Line } 19 \text { reads: } \\
\text { There were transported for them (the quarry } \\
\text { workers), supplies from Egypt in } 10 \text { carts, there } \\
\text { being six yoke of oxen to each cart drawing them } \\
\text { (H) mathe }\end{array}$ \\
\hline
\end{tabular}




\begin{tabular}{|c|c|c|c|}
\hline & & & $\begin{array}{l}\text { Hr kmt nfryt } \mathrm{r} \text { pA Dw n bxn } \\
\text { From Egypt until the mountain of Bekhen. } \\
8362 \text { workers were employed in the expedition. This } \\
\text { number is exclusive of } 900 \text { who died from the desert } \\
\text { journey and from the labor in the quarry. }\end{array}$ \\
\hline 11 & $\begin{array}{l}\text { Rock inscription of } \\
\text { an unknown } \\
\text { person. }{ }^{17}\end{array}$ & $\begin{array}{c}\text { Ramses IV - } \\
20^{\text {th }} \text { Dynasty, } \\
\text { New } \\
\text { Kingdom. }\end{array}$ & $\begin{array}{l}\text { A single line of hieratic reading as follows: } \\
\text { Mouth of the mountain of Bekhenw. }\end{array}$ \\
\hline 12 & $\begin{array}{l}\text { The statue was } \\
\text { purchased in } \\
\text { Memphis for } \\
\text { Petrie collection, } \\
\text { London. }\end{array}$ & $\begin{array}{l}26^{\text {th }} \text { Dynasty, } \\
\text { Late period. }\end{array}$ & 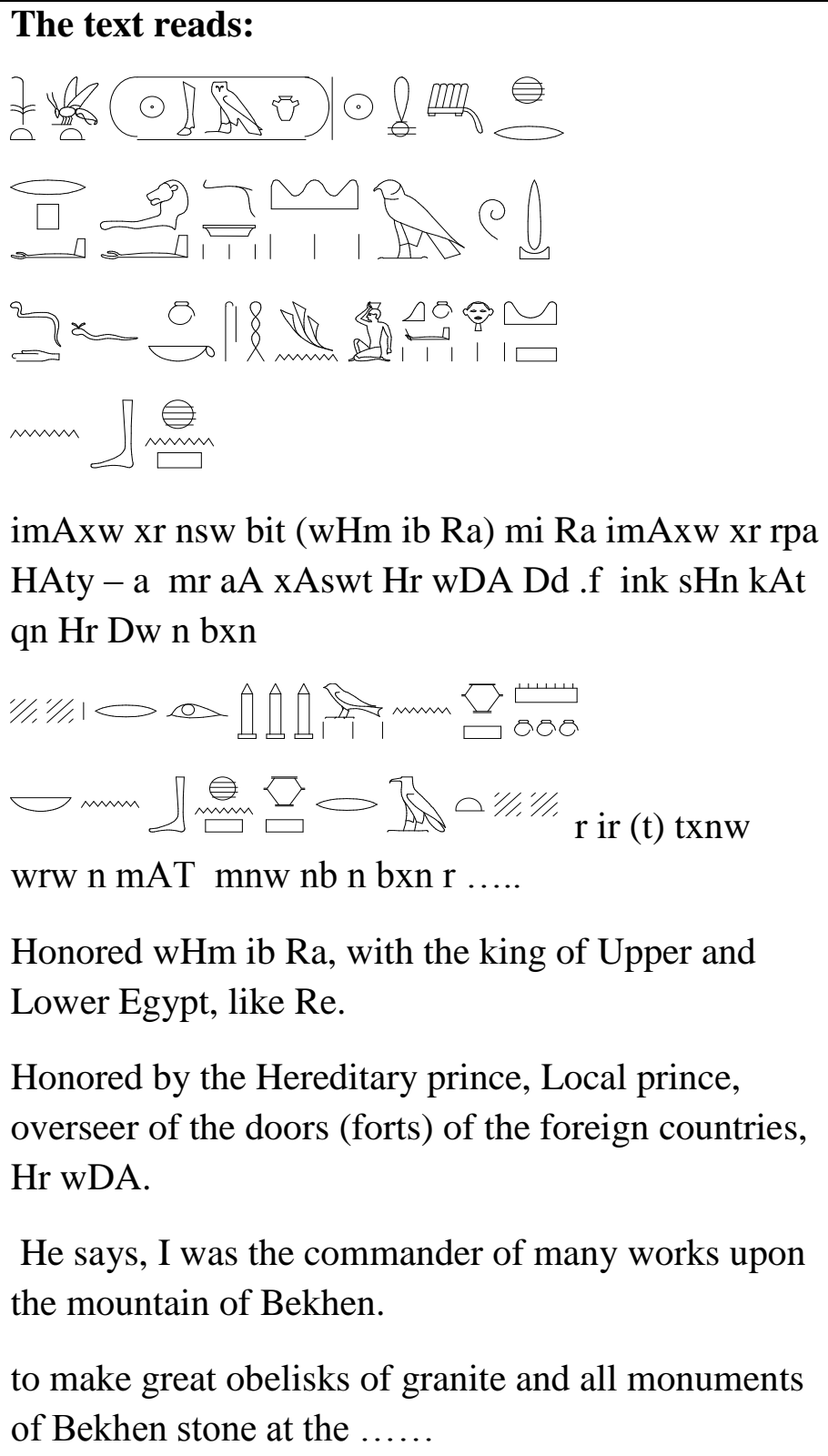 \\
\hline
\end{tabular}




\begin{tabular}{|c|c|c|c|}
\hline 13 & $\begin{array}{l}\text { Naos of Amasis II, } \\
\text { tell Atrib (near } \\
\text { Banha) - Egyptian } \\
\text { Museum - (lid } \\
\text { only), Cairo. } \\
\text { Cat. Gen. } 70011 \\
\text { JE, } 40034-43101 . \\
19\end{array}$ & $\begin{array}{l}26^{\text {th }} \text { Dynasty, } \\
\text { Late period. }\end{array}$ & $\begin{array}{l}\text { This monument was dedicated to the god "Km }-\mathrm{Wr} \text { " } \\
\text { by the king who states: } \\
\text { Ir .n .f } \mathrm{m} \text { mnw .f } \mathrm{n} \text { it .f km - wr nTr aA xnty sxt Htp } \\
\mathrm{kAr} \text { Sps } \mathrm{m} \text { bxn } \\
\text { He made (it) as his monument for his father Kem - } \\
\text { Wer, the great god who is in frontof Sekhet - Hetep, } \\
\text { a notable naos of Bekhen stone. } \\
\text { "Km - Wr" was the surname of Osiris of Athribis. }\end{array}$ \\
\hline 14 & $\begin{array}{c}\text { Green breccia } \\
\text { Naos of (Nxt - nb } \\
\text {.f) Nectanebo I, } \\
\text { Coptos - Cairo, } \\
\text { Egyptian Museum. } \\
\text { Cat. Gen. } 70019 .{ }^{20}\end{array}$ & $\begin{array}{l}30^{\text {th }} \text { Dynasty, } \\
\text { Late Period. }\end{array}$ & $\begin{array}{l}\text { The monument which was dedicated to the god "Mn } \\
-\mathrm{Hr} \text { ", is described as: } \\
\text { kAr m inr } \mathrm{n} \text { bxn tHn } \\
\text { Naos of sparkling stone of Bekhen. }\end{array}$ \\
\hline 15 & $\begin{array}{l}\text { Part of frieze of } \\
\text { Nectanebo I- } \\
\text { Found on the } \\
\text { Aventine hil in } \\
\text { Rome and } \\
\text { preserved now in } \\
\text { the Museo Civico } \\
\text { in Bologna. }\end{array}$ & $\begin{array}{l}30^{\text {th }} \text { Dynasty, } \\
\text { Late period. }\end{array}$ & $\begin{array}{l}\text { A horizontal text on the top of the monument } \\
\text { contains the words: } \\
\text {.. m bxn } \\
\text { of Bekhen stone } \\
\text { It is impossible to indicate in which connection as } \\
\text { the beginning of the text is missing. }\end{array}$ \\
\hline 16 & $\begin{array}{c}\text { Two small } \\
\text { obelisks with } \\
\text { missing parts of } \\
\text { Nectanebo II - } \\
\text { now preserved in } \\
\text { the British } \\
\text { Museum, no. } 523- \\
524 .{ }^{22}\end{array}$ & $\begin{array}{c}\text { XXXth } \\
\text { Dynasty, } \\
\text { Late period. }\end{array}$ & $\begin{array}{l}\text { These monuments were dedicated to the god Thot of } \\
\text { Hermopolis, and on each of them the king informs us } \\
\text { that: } \\
\text { SaHa .n .f txn m pr .f n bxn bnbn .f m Hmt } \\
\text { Bekhen stone with a pyramidion of black copper. }\end{array}$ \\
\hline
\end{tabular}




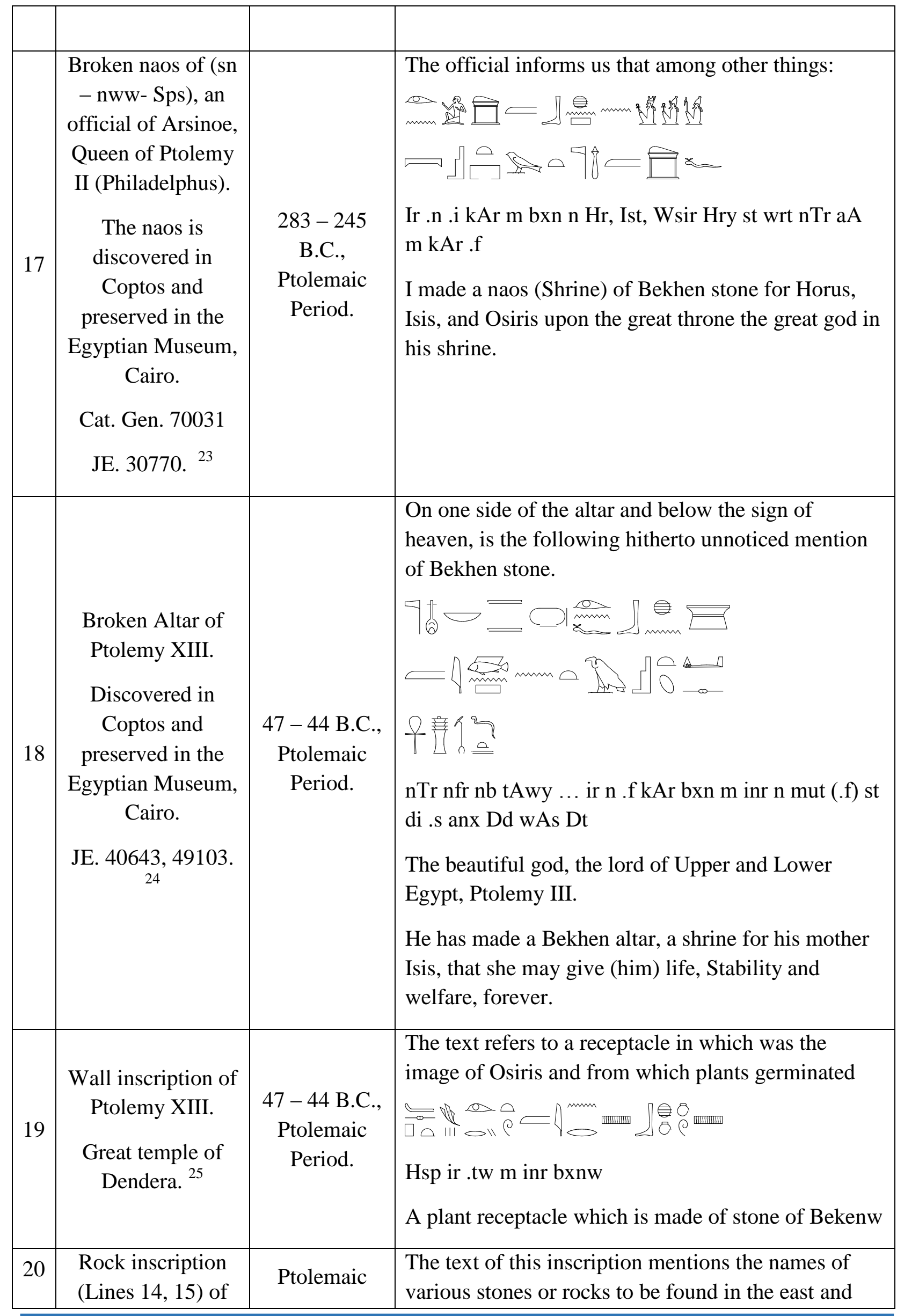




\begin{tabular}{|c|c|c|}
\hline $\begin{array}{l}\text { the Famine Stela - } \\
\text { Siheil Island, } \\
\text { Aswan. }{ }^{26}\end{array}$ & Period. & $\begin{array}{l}\text { west, in the river of Elephantine and in the heart of } \\
\text { Elephantine including Bekhen stone that varied in } \\
\text { two different publications by Brugsch and De } \\
\text { Morgan as follows: } \\
\text { Brugsch: }\end{array}$ \\
\hline
\end{tabular}

\section{Greywacke quarries of Wadi Hammamat}

The ancient quarrying activities in Wadi Hammamat were executed in two quarries that are separated by $1 \mathrm{~km}^{27}$

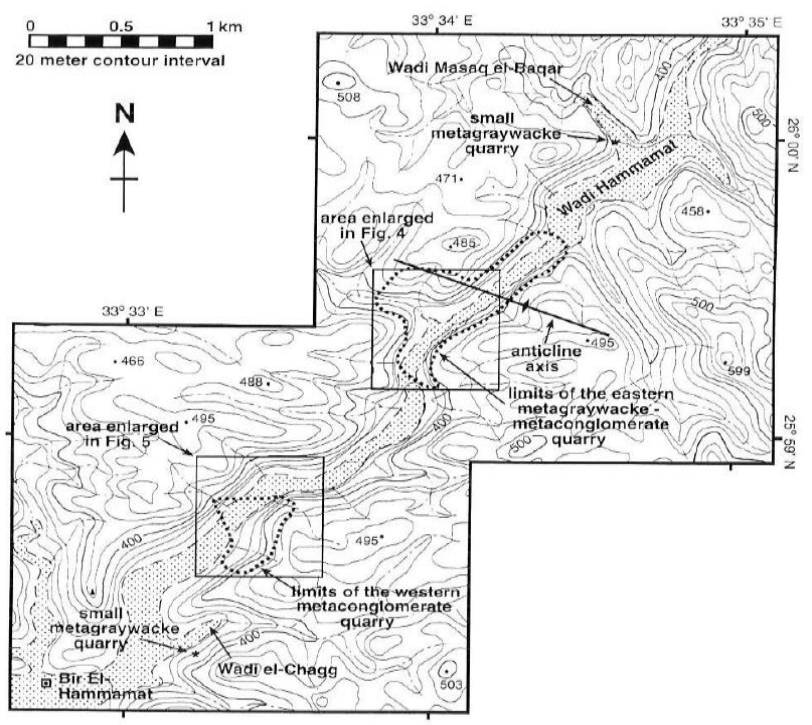

Fig. 1

The Topographic contours of Wadi Hammamat quarries After: J. A. Harrell, V. M. Brown, and L. Lazzarini, "Breccia Verde Antica", 


\section{The Eastern Quarry}

The easternmost of these (coordinates $25^{\circ} 59.40^{\prime} \mathrm{N} ; 33^{\circ} 34.05^{\prime} \mathrm{E}$ ), is well known today because of the thousands of extant objects carved from its meta-greywacke and because of the hundreds of inscriptions cut into its walls dating from the early dynastic period (about 2900 BC) through the early third century AD of the Roman period. ${ }^{28}$

On the west side of the wadi, the only traces of quarrying are seen in bed 2 . However, the conspicuous workings seen there today are entirely modern. They date from about 1988 and resulted from a joint quarrying venture of the Egyptian geological survey and mining authority, the "Marmonil" company and another Italian Egyptian company, "Petrobel". The rock that Marmonil currently markets as breccia Fawakhir was apparently obtained from bed 2. This recent activity destroyed much of the evidence of the ancient quarrying in this bed. However Roman wedge holes and inscriptions dating to the reign of king Ramses IV (about 1150 BC) still survive on some blocks, which are probably associated with the only quarrying of this rock during the Twentieth Dynasty. ${ }^{29}$

Marks were not seen on the bedrock surfaces except at one place in bed 1 where there are few wedge holes. Blocks of stone must have been dislodged mainly by driving iron wedges into natural fractures. Rather than pre-cut holes, and then maneuvered downslope with levers and ropes. The two meta-conglomerate beds in the eastern quarry, lie either flush with or slightly protruding from the wadi walls, and do not look like they have lost much material through quarrying. The vast bulk of the meta-conglomerate taken from Wadi Hammamat must have come from the western quarry. ${ }^{30}$

\section{The Western Quarry}

The western quarry is Located just southwest and within sight of the eastern quarry (coordinates $\left.25^{\circ} 58.66^{\prime} \mathrm{N}, 33^{\circ} 33.40^{\prime} \mathrm{E}\right)$. Here there are two especially massive beds of meta-conglomerate with a thickness of $65 \mathrm{~m}$ (1) and $80 \mathrm{~m}$ (2). These are stratigraphically above the rocks in the eastern quarry and lie on the southwest flank of the same anticline.

The south-westerly dips in the western quarry vary from $40^{\circ}$ in bed 1 to nearly vertical in bed 2 , The area of most intense quarrying is in bed 1 on the east side of the wadi. There are traces of minor activity in this bed on the west side and in bed 2 on the east side. Both between the two meta-conglomerate beds and stratigraphically above them to the west are thick sequences of meta-greywacke, which are occasionally pebbly and contain thin lenses (up to several meters thick) of meta-conglomerate. The latter were extensively worked in the southwest part of the quarry, where there are several Roman slipways. From a few worked blocks near the Roman ruins, some pebbly meta-greywacke was also quarried. Probably from the outcrops above the ruins. Moreover, there is a small previous known meta-greywacke quarry, several hundred meters to the south, near Wadi el - Chagg, which is of indeterminate age. ${ }^{31}$

In bed 1, south of the ruins, the meta-conglomerate is well jointed and tends to naturally separate from the bedrock in sub-rectangular blocks. There are no excavation pits, slip-ways or tool marks in this area. The only indications of quarrying are the numerous sites where light coloured joint surfaces were exposed after removal of the overlying blocks. ${ }^{32}$ 
Given the evidence of the tool marks and the known use of the meta-conglomerate, it is certain that the settlement was occupied during the Roman Period (first three centuries A.D.). It is also possible, of course, that some of the structures go back to the late period (Eighth through Fourth centuries B.C.). ${ }^{33}$

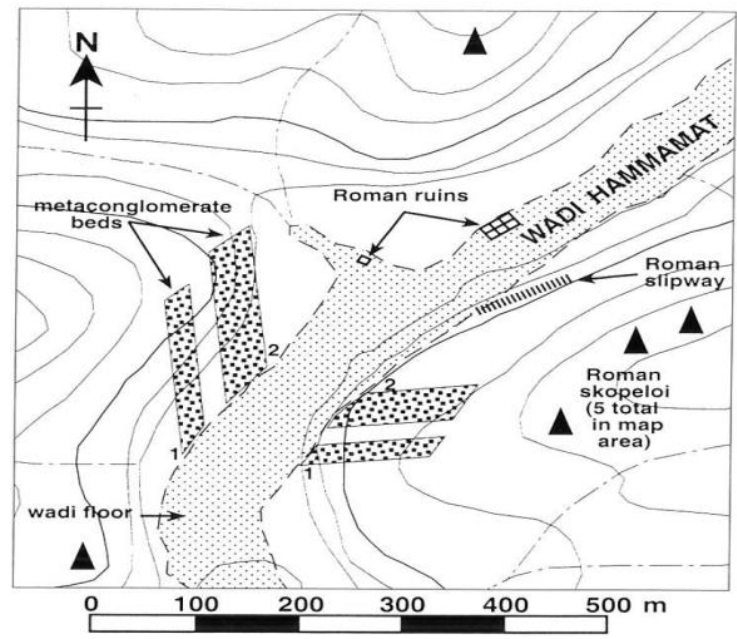

A

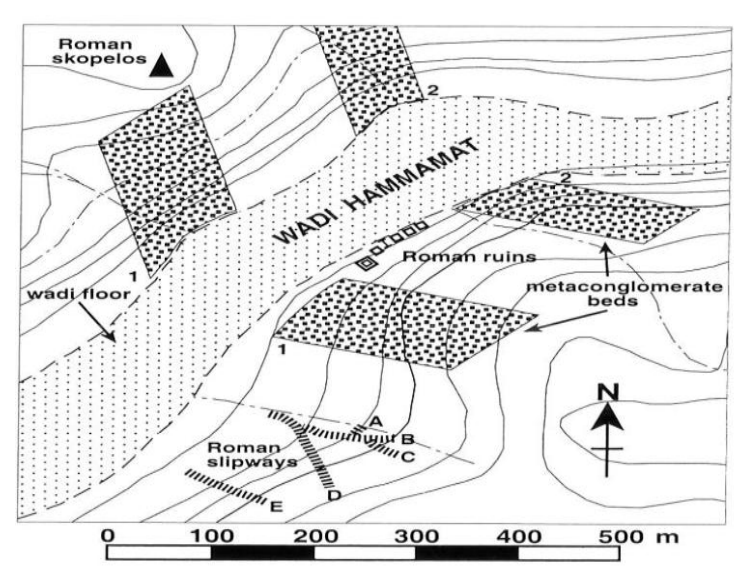

B

Fig. 2

A. The Eastern Quarry of Wadi Hammama, After: J. A. Harrell, V. M. Brown, and L. Lazzarini, "Breccia Verde Antica", 209, fig. 4.

B. The Western Quarry of Wadi Hammamat, After: J. A. Harrell, V. M. Brown, and L. Lazzarini, "Breccia Verde Antica", 209, fig. 5.

\section{Chronological List of Greywacke Objects}

The following list summarizes a catalogue of greywacke objects preserved in the museums around the world. This catalogue is prepared by the researcher as a part of the recent study to represent the variety of products sculpted from Wadi Hammamat greywacke and their chronological sequence such as:

Palettes: 35 pieces.

Minor arts (Amulets - scarabs - Jewelry - offering tables - Figurines - Ushabtis - Magical stelae): 21 pieces.

Statues: 88 pieces.

Utensils (Vases, tools, dishes, cups, trays, knives, vessels, bowls, Mace - heads): 24.

Sarcophagi: 10 pieces.

Obelisks, Naoi and architectural elements: 3 pieces. 


\begin{tabular}{|c|c|c|}
\hline \multicolumn{3}{|c|}{ Pre-dynastic and Early Dynastic Period } \\
\hline No. & Object & Museum \\
\hline 1 & $\begin{array}{l}\text { Fragment of the Libyan Tribute Palette. } \\
\text { Inv. no: (JE } 27434 \text { - CG 14238). }\end{array}$ & $\begin{array}{l}\text { Egyptian Museum, Cairo, } \\
\text { Egypt. }\end{array}$ \\
\hline 2 & $\begin{array}{c}\text { Narmer's Palette. } \\
\text { Inv. no: }(\text { JE } 32169-\text { CG 14716) } \\
\text { Inv. no: }(\text { EA35714) }\end{array}$ & $\begin{array}{l}\text { Egyptian Museum, Cairo, } \\
\text { Egypt. } \\
\text { British Museum. }\end{array}$ \\
\hline 3 & $\begin{array}{l}\text { Necklace from the Thinite age. } \\
\text { Inv. no: (JE 87499). }\end{array}$ & $\begin{array}{l}\text { Egyptian Museum, Cairo, } \\
\text { Egypt. }\end{array}$ \\
\hline 4 & $\begin{array}{l}\text { Vase with names of Pharaohs. } \\
\text { Inv. no: (JE 88345). }\end{array}$ & $\begin{array}{l}\text { Egyptian Museum, Cairo, } \\
\text { Egypt. }\end{array}$ \\
\hline 5 & $\begin{array}{l}\text { Basket - Shaped Tray. } \\
\text { Inv. no: (JE 71298). }\end{array}$ & $\begin{array}{l}\text { Egyptian Museum, Cairo, } \\
\text { Egypt. }\end{array}$ \\
\hline 6 & $\begin{array}{l}\text { Statue of Khasekhem. } \\
\text { Inv. no: (JE 32161). }\end{array}$ & $\begin{array}{l}\text { Egyptian Museum, Cairo, } \\
\text { Egypt. }\end{array}$ \\
\hline 7 & $\begin{array}{c}\text { Fish - Shaped Palette. } \\
\text { Inv. no: }(\text { S.4956). }\end{array}$ & $\begin{array}{l}\text { Egyptian Museum of Turin, } \\
\text { Italy. }\end{array}$ \\
\hline 8 & $\begin{array}{c}\text { Geometric and Zoomorphic Cosmetic Palettes. } \\
\text { Inv. no: (S. } 604 \text { - S. } 605 \text { - S. } 606 \text { - S. } 618 \text { - S. } 619 \\
\text { S. } 634 \text { - S. } 4955 \text { - S. } 4956 \text { - S. } 3959 / 3 \\
\text { S. 17504). }\end{array}$ & $\begin{array}{l}\text { Egyptian Museum of Turin, } \\
\text { Italy. }\end{array}$ \\
\hline 9 & $\begin{array}{c}\text { Rhomboidal Cosmetics Palette. } \\
\text { Inv. no: (I.6) }\end{array}$ & $\begin{array}{l}\text { National museum of } \\
\text { Antiquities, Leiden, Holland } \\
\text { - Exhibition in Bologna, } \\
\text { Italy. }\end{array}$ \\
\hline 10 & $\begin{array}{l}\text { Zoomorphic Cosmetic Palettes. } \\
\text { Inv. no: (I.7) }\end{array}$ & $\begin{array}{l}\text { National museum of } \\
\text { Antiquities, Leiden, Holland } \\
\text { - Exhibition in Bologna, } \\
\text { Italy. }\end{array}$ \\
\hline 11 & $\begin{array}{l}\text { Bird - Shaped Plaque. } \\
\text { Inv. no: (I.8) }\end{array}$ & $\begin{array}{l}\text { National museum of } \\
\text { Antiquities, Leiden, Holland } \\
\text { - Exhibition in Bologna, } \\
\text { Italy. }\end{array}$ \\
\hline 12 & $\begin{array}{l}\text { Rectangular Cosmetic Palette. } \\
\text { Inv. no: (I.20) }\end{array}$ & $\begin{array}{l}\text { National museum of } \\
\text { Antiquities, Leiden, Holland } \\
\text { - Exhibition in Bologna, } \\
\text { Italy. }\end{array}$ \\
\hline 13 & $\begin{array}{l}\text { Rectangular Cosmetic Palette. } \\
\text { Inv. no: (I.40c) }\end{array}$ & $\begin{array}{l}\text { National museum of } \\
\text { Antiquities, Leiden, Holland } \\
\text { - Exhibition in Bologna, } \\
\text { Italy. }\end{array}$ \\
\hline 14 & $\begin{array}{c}\text { Fish - Figured Greywacke Palettes. } \\
\text { Inv. no: (E 22730 - E } 22731 \text { - E 24731 - E } 32283 \\
\text { E 24728 - E 24724 - E 28061 - AF 6908). }\end{array}$ & $\begin{array}{l}\text { Louvre Museum, Paris, } \\
\text { France. }\end{array}$ \\
\hline 15 & $\begin{array}{c}\text { A Pre - dynastic Greywacke Palette. } \\
\text { Inv. no: (E } 27209 \text { - E } 14230 \text { - E } 17337 \\
\text { AF } 6909 \text { - E 10726). }\end{array}$ & $\begin{array}{l}\text { Louvre Museum, Paris, } \\
\text { France. }\end{array}$ \\
\hline 16 & $\begin{array}{l}\text { Pre - dynastic Greywacke Palettes. } \\
\text { Inv. no: (E } 24727 \text { - E 24729). }\end{array}$ & $\begin{array}{l}\text { Louvre Museum, Paris, } \\
\text { France. }\end{array}$ \\
\hline 17 & Model of a Piece of Meat. & Louvre Museum, Paris, \\
\hline
\end{tabular}




\begin{tabular}{|c|c|c|}
\hline & Inv. no: (E 17279). & France. \\
\hline 18 & $\begin{array}{l}\text { Base of a Palette. } \\
\text { Inv. no: (E 11256). }\end{array}$ & $\begin{array}{l}\text { Louvre Museum, Paris, } \\
\text { France. }\end{array}$ \\
\hline 19 & $\begin{array}{c}\text { A Fragment of a Palette with an Ibex. } \\
\text { (E 11648). }\end{array}$ & $\begin{array}{l}\text { Louvre Museum, Paris, } \\
\text { France. }\end{array}$ \\
\hline 20 & $\begin{array}{c}\text { The Hunter's Palette. } \\
\text { Inv. no: (E 11254). }\end{array}$ & $\begin{array}{l}\text { Louvre Museum, Paris, } \\
\text { France. }\end{array}$ \\
\hline 21 & $\begin{array}{l}\text { Greywacke Cup. } \\
\text { Inv. no: (AF 9161). }\end{array}$ & $\begin{array}{l}\text { Louvre Museum, Paris, } \\
\text { France. }\end{array}$ \\
\hline 22 & $\begin{array}{l}\text { Palette Depicting a Pair of Mud Turtles. } \\
\text { Inv. no: }(10.176 .78) .\end{array}$ & Metropolitan Museum of Art. \\
\hline 23 & $\begin{array}{l}\text { Greywacke Palette. } \\
\text { Inv. no: }(10.176 .80)\end{array}$ & Metropolitan Museum of Art. \\
\hline 24 & $\begin{array}{l}\text { Carved Ceremonial Palette. } \\
\text { Inv. no: }(28.9 .8) \text {. }\end{array}$ & Metropolitan Museum of Art. \\
\hline 25 & $\begin{array}{l}\text { Fragment of a Ceremonial Palette. } \\
\text { Inv. no: }(33.159) \text {. }\end{array}$ & Metropolitan Museum of Art. \\
\hline 26 & $\begin{array}{l}\text { A Leaf - Shaped Dish. } \\
\text { Inv. no: }(19.2 .17) .\end{array}$ & Metropolitan Museum of Art. \\
\hline 27 & $\begin{array}{l}\text { Libation Dish Depicting “Ka" Arms } \\
\text { Presenting the Ankh-Sign. } \\
\text { Inv. no: }(19.2 .16) .\end{array}$ & Metropolitan Museum of Art. \\
\hline 28 & $\begin{array}{c}\text { Inscribed Greywacke Dish. } \\
\text { Inv. no: }(68.15) . \\
\end{array}$ & Metropolitan Museum of Art. \\
\hline 29 & $\begin{array}{l}\text { Fragment of Rectangular Palette. } \\
\text { Inv. no: }(05.261) \text {. }\end{array}$ & Boston Museum of Fine Arts. \\
\hline 30 & $\begin{array}{l}\text { Rhomboid Palette. } \\
\text { Inv. no: }(11.208) \text {. }\end{array}$ & Boston Museum of Fine Arts. \\
\hline 31 & $\begin{array}{c}\text { Double - Bird Palette. } \\
\text { Inv. no: }(11.226 \mathrm{a}-\mathrm{b}-11.228)\end{array}$ & Boston Museum of Fine Arts. \\
\hline 32 & $\begin{array}{l}\text { Shield - Shaped Palette. } \\
\text { Inv. no: (03.1488). }\end{array}$ & Boston Museum of Fine Arts. \\
\hline 33 & $\begin{array}{l}\text { Fish-Shaped Palette. } \\
\text { Inv. no: (47.1639). }\end{array}$ & Boston Museum of Fine Arts. \\
\hline 34 & $\begin{array}{l}\text { Disc - Shaped Palette. } \\
\text { Inv. no: }(11.202) \text {. }\end{array}$ & Boston Museum of Fine Arts. \\
\hline 35 & $\begin{array}{l}\text { Sandal - Shaped Palette. } \\
\text { Inv. no: }(03.1484) .\end{array}$ & Boston Museum of Fine Arts. \\
\hline 36 & $\begin{array}{l}\text { Turtle - Shaped Palette. } \\
\text { Inv. no: (47.1644). }\end{array}$ & Boston Museum of Fine Arts. \\
\hline 37 & $\begin{array}{l}\text { Rectangular Palette. } \\
\text { Inv. no: (47.1637). }\end{array}$ & Boston Museum of Fine Arts. \\
\hline 38 & $\begin{array}{l}\text { Double Bird - Headed Palette. } \\
\text { Inv. no: }(47.1640) \text {. }\end{array}$ & Boston Museum of Fine Arts. \\
\hline 39 & $\begin{array}{l}\text { Rectangular Palette. } \\
\text { Inv. no: }(11.2496) .\end{array}$ & Boston Museum of Fine Arts. \\
\hline 40 & $\begin{array}{l}\text { Fragmented Knife. } \\
\text { Inv. no: (UC35710). }\end{array}$ & Petrie Museum. \\
\hline 41 & Group of Tools. & Petrie Museum. \\
\hline
\end{tabular}




\begin{tabular}{|c|c|c|}
\hline & Inv. no: (UC73456). & \\
\hline 42 & $\begin{array}{c}\text { Geological Sample. } \\
\text { Inv. no: (UC26877). }\end{array}$ & Petrie Museum. \\
\hline 43 & $\begin{array}{c}\text { Palette. } \\
\text { Inv. no: (UC25510). }\end{array}$ & Petrie Museum. \\
\hline 44 & $\begin{array}{c}\text { Palette. } \\
\text { Inv. no: (UC26516). }\end{array}$ & Petrie Museum. \\
\hline 45 & $\begin{array}{c}\text { Vase. } \\
\text { Inv. no: (UC41079). }\end{array}$ & Petrie Museum. \\
\hline 46 & $\begin{array}{c}\text { Fragmented Dish. } \\
\text { Inv. no: (UC37034). }\end{array}$ & Petrie Museum. \\
\hline 47 & $\begin{array}{c}\text { Fragmented Vessel. } \\
\text { Inv. no: (UC37042). }\end{array}$ & Petrie Museum. \\
\hline 48 & $\begin{array}{c}\text { Plant Leaf Model. } \\
\text { Inv. no: (UC35653). }\end{array}$ & Petrie Museum. \\
\hline 49 & $\begin{array}{c}\text { Writing palette. } \\
\text { Inv. no: (UC2475). } \\
\text { Piece of a cup. }\end{array}$ & Petrie Museum. \\
\hline 50 & \begin{tabular}{c} 
Inv. no: (UC37048). \\
\hline
\end{tabular}
\end{tabular}
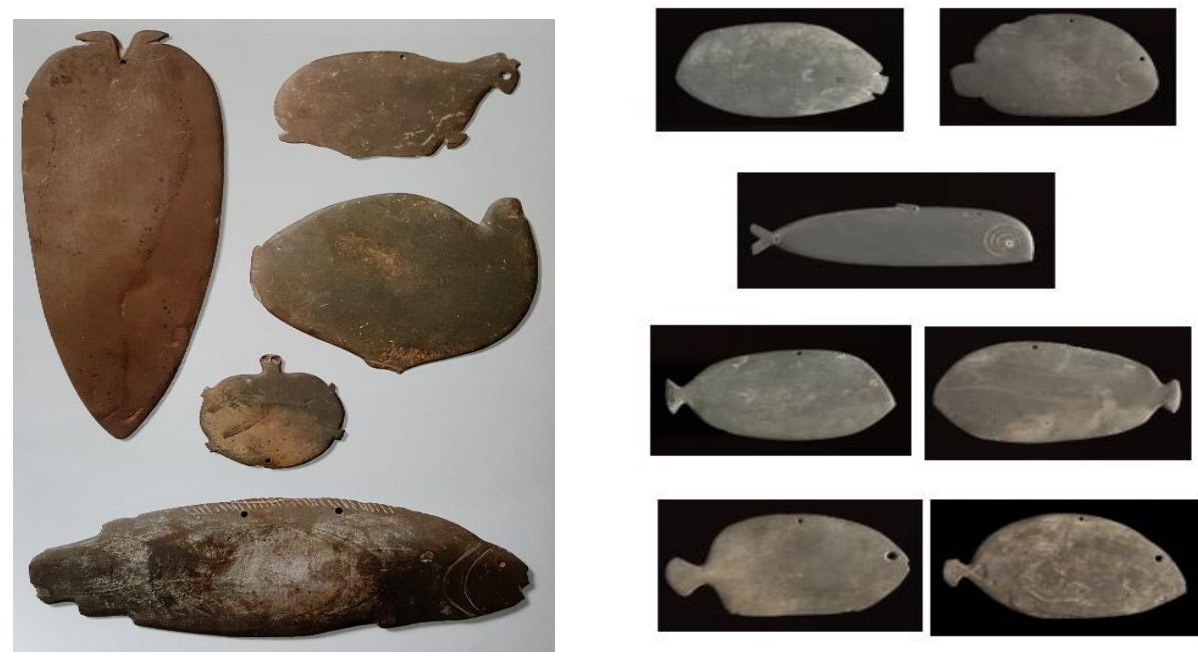

Zoomorphic cosmetic palettes: Pre-dynastic period, Naqada IC - II (National museum of Antiquities, Leiden, Holland - Exhibition in Bologna, Italy).

Fish - figured Greywacke Palettes: 3600 - 3200 BC. (Louvre Museum, Paris, France, Nos. E 22730, E 22731, E 24731, E 32283, E 24728, E 24724, E 28061, AF 6908).
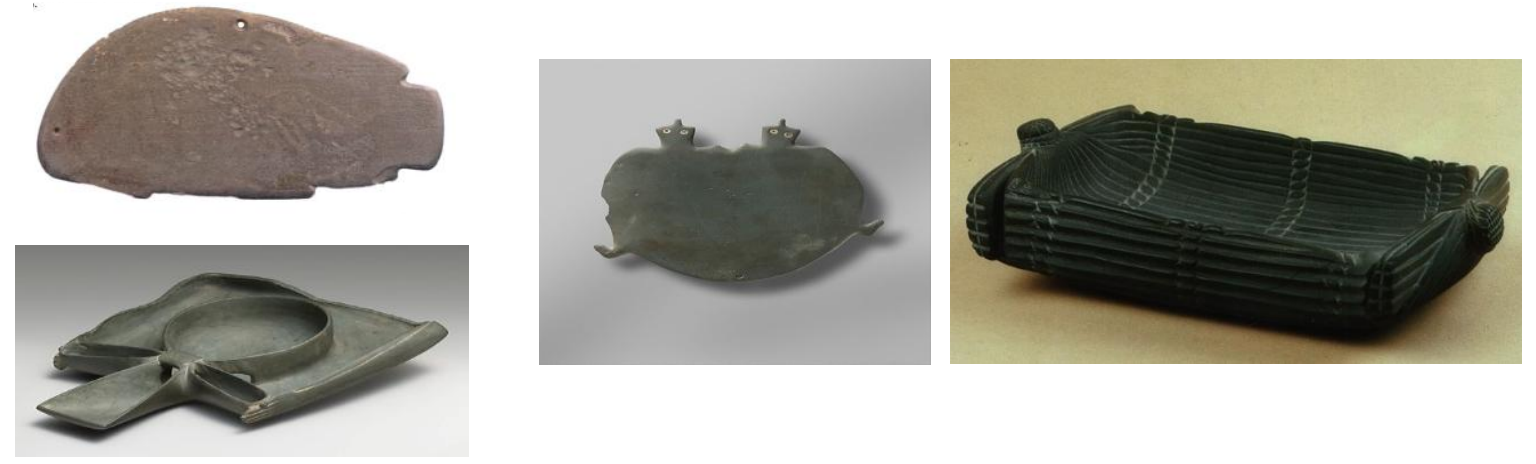
Fish - Shaped Palette: Pre-dynastic period (Naqada II 3700 - 3300 B.C.) - ( Egyptian Museum of Turin, Italy - no. S.4956).

Palette Depicting a Pair of Mud Turtles: Pre-dynastic, Early Naqada II (ca. 36503500 B.C.) - (The Metropolitan Museum of Art - no. 10.176.78).

Libation Dish Depicting Ka-Arms Presenting an Ankh-Sign: Early Dynastic Period (Dynasty 1, ca. 3100-2900 B.C.) - (The Metropolitan Museum of Art, No. 19.2.16). Basket - Shaped Tray: $2^{\text {nd }}$ Dynasty $(2770-2649$ BC) - (Egyptian Museum, Cairo - Room 43, JE 71298).

\begin{tabular}{|c|c|c|}
\hline \multicolumn{3}{|c|}{ Old Kingdom } \\
\hline 1 & $\begin{array}{l}\text { Two Unidentified Statues of king Chefren. } \\
\text { Room } 42 .\end{array}$ & $\begin{array}{l}\text { Egyptian Museum, Cairo, } \\
\text { Egypt. }\end{array}$ \\
\hline 2 & $\begin{array}{c}\text { Triads of Menkaure. } \\
\text { Inv. no: (JE } 40678 \text { - JE } 46499 \text { - JE 40679). }\end{array}$ & $\begin{array}{l}\text { Egyptian Museum, Cairo, } \\
\text { Egypt. }\end{array}$ \\
\hline 3 & $\begin{array}{c}\text { Head of Userkaef. } \\
\text { Inv. no: (JE 90220). }\end{array}$ & $\begin{array}{l}\text { Egyptian Museum, Cairo, } \\
\text { Egypt. }\end{array}$ \\
\hline 4 & $\begin{array}{l}\text { Bucket with a hole for suspension. } \\
\text { Inv. no: (E 932). }\end{array}$ & $\begin{array}{l}\text { Louvre Museum, Paris, } \\
\text { France. }\end{array}$ \\
\hline 5 & $\begin{array}{l}\text { Kneeling Statuette of Pepy I. } \\
\text { Inv. no: }(39.121) .\end{array}$ & $\begin{array}{l}\text { Brooklyn Museum, New } \\
\text { York. }\end{array}$ \\
\hline 6 & $\begin{array}{l}\text { Model of the "Opening of the Mouth" ritual } \\
\text { equipment. } \\
\text { Inv. no: }(07.228 .117 \mathrm{a}-\mathrm{h}) \text {. }\end{array}$ & Metropolitan Museum of Art. \\
\hline 7 & $\begin{array}{c}\text { King Menkaure and his queen. } \\
\text { Inv. no: }(11.1738) \text {. }\end{array}$ & Boston Museum of Fine Arts. \\
\hline 8 & $\begin{array}{c}\text { Bowl. } \\
\text { Inv. no: (UC41083). }\end{array}$ & Petrie Museum. \\
\hline 9 & $\begin{array}{c}\text { Bowl. } \\
\text { Inv. no: (UC17745). }\end{array}$ & Petrie Museum. \\
\hline 10 & $\begin{array}{c}\text { Mace-head. } \\
\text { Inv. no: (UC19749). }\end{array}$ & Petrie Museum. \\
\hline 11 & $\begin{array}{c}\text { Palette. } \\
\text { Inv. no: (UC18091). }\end{array}$ & Petrie Museum. \\
\hline
\end{tabular}
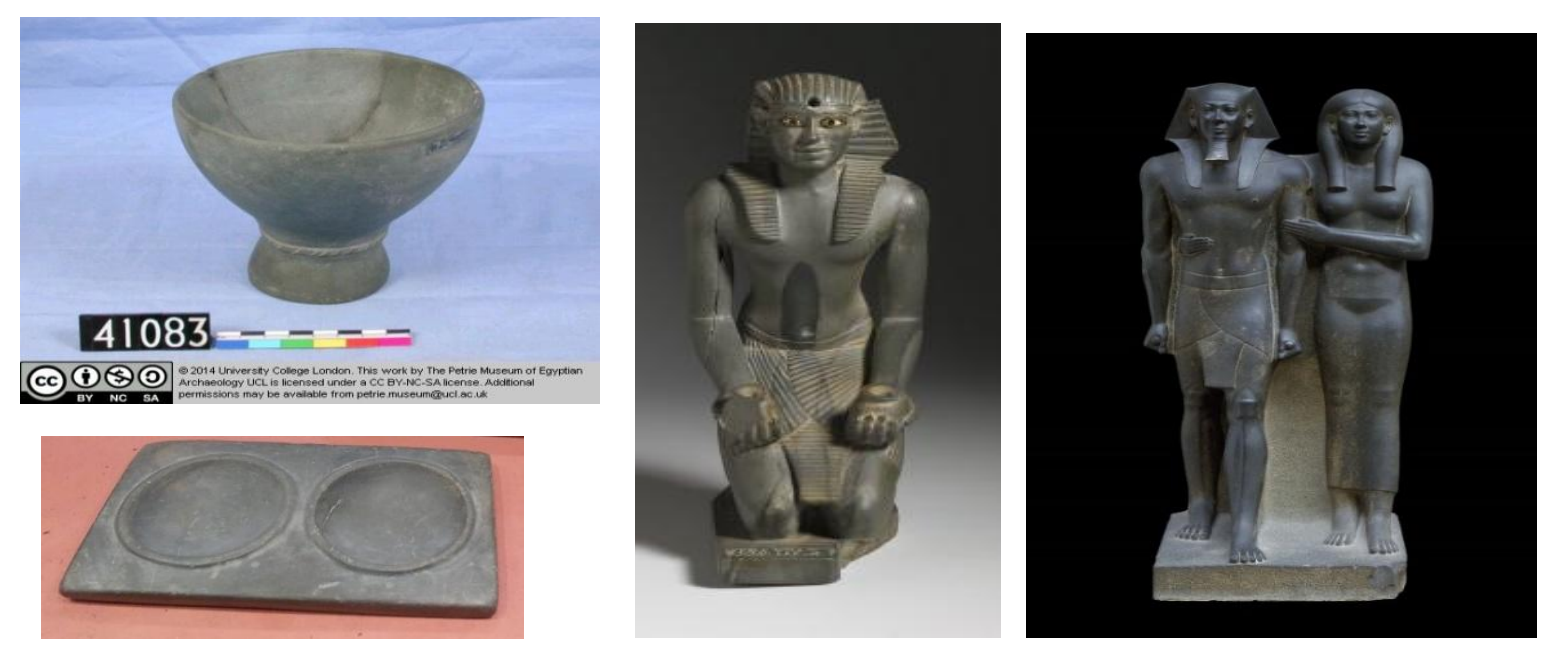
Bowl: Old Kingdom, $3^{\text {rd }}$ Dynasty - (Petrie Museum, no. UC41083).

Bucket with a hole for suspension: Old Kingdom (2700 - 2200 BC) - (Louvre Museum, Paris, France - No. E 932).

Kneeling Statuette of Pepy I: Old Kingdom (6 ${ }^{\text {th }}$ Dynasty, ca. 2338-2298 B.C.) - (Brooklyn Museum, New York - no. 39.121).

King Menkaure and his queen: Old Kingdom (2490-2472 B.C. $-4^{\text {th }}$ Dynasty) - (Boston Museum of Fine Arts, no. 11.1738).

\begin{tabular}{|c|c|c|}
\hline \multicolumn{3}{|c|}{ Middle Kingdom } \\
\hline 1 & $\begin{array}{l}\text { Head of a Sphinx of Sesostris III / Amenemhat } \\
\text { III. } \\
\text { Inv. no: }(387) .\end{array}$ & $\begin{array}{l}\text { National Archaeological } \\
\text { Museum of Naples, Italy. }\end{array}$ \\
\hline 2 & $\begin{array}{c}\text { Statue of king Amenemhat III. } \\
\text { Inv. no: (N 464). }\end{array}$ & $\begin{array}{l}\text { Louvre Museum, Paris, } \\
\text { France. }\end{array}$ \\
\hline 3 & $\begin{array}{c}\text { Head of a king. } \\
\text { Inv. no: (E 10299). }\end{array}$ & $\begin{array}{l}\text { Louvre Museum, Paris, } \\
\text { France. }\end{array}$ \\
\hline 4 & $\begin{array}{l}\text { Head of a woman. } \\
\text { Inv. no: (E 22756). }\end{array}$ & $\begin{array}{l}\text { Louvre Museum, Paris, } \\
\text { France. }\end{array}$ \\
\hline 5 & $\begin{array}{l}\text { Head of a man. } \\
\text { Inv. no: }(\mathrm{E} 10757) \text {. }\end{array}$ & $\begin{array}{l}\text { Louvre Museum, Paris, } \\
\text { France. }\end{array}$ \\
\hline 6 & Iay, Chief of the treasury. Inv. no: (N 870). & $\begin{array}{l}\text { Louvre Museum, Paris, } \\
\text { France. }\end{array}$ \\
\hline 7 & $\begin{array}{c}\text { Seated Statue of King Senwosret I. } \\
\text { Inv. no: }(25.6) \text {. }\end{array}$ & Metropolitan Museum of Art. \\
\hline 8 & $\begin{array}{c}\text { Offering table with statuette of "Se-hetep-ib". } \\
\text { Inv. no: }(22.1 .107 \mathrm{a}, \mathrm{b}) \text {. }\end{array}$ & Metropolitan Museum of Art. \\
\hline 9 & $\begin{array}{c}\text { Statuette of a striding man. } \\
\text { Inv. no: }(07.228 .180)\end{array}$ & Metropolitan Museum of Art. \\
\hline 10 & $\begin{array}{l}\text { Middle Kingdom reused statuette from } \\
\text { Byblos. Inv. no: }(68.101) \text {. }\end{array}$ & Metropolitan Museum of Art. \\
\hline 11 & $\begin{array}{c}\text { Middle Kingdom Head. } \\
\text { Inv. no: }(28.2 .1)\end{array}$ & Metropolitan Museum of Art. \\
\hline 12 & Figurine. Inv. no: (UC14815). & Petrie Museum. \\
\hline 13 & Dish. Inv. no: (UC41369). & Petrie Museum. \\
\hline
\end{tabular}
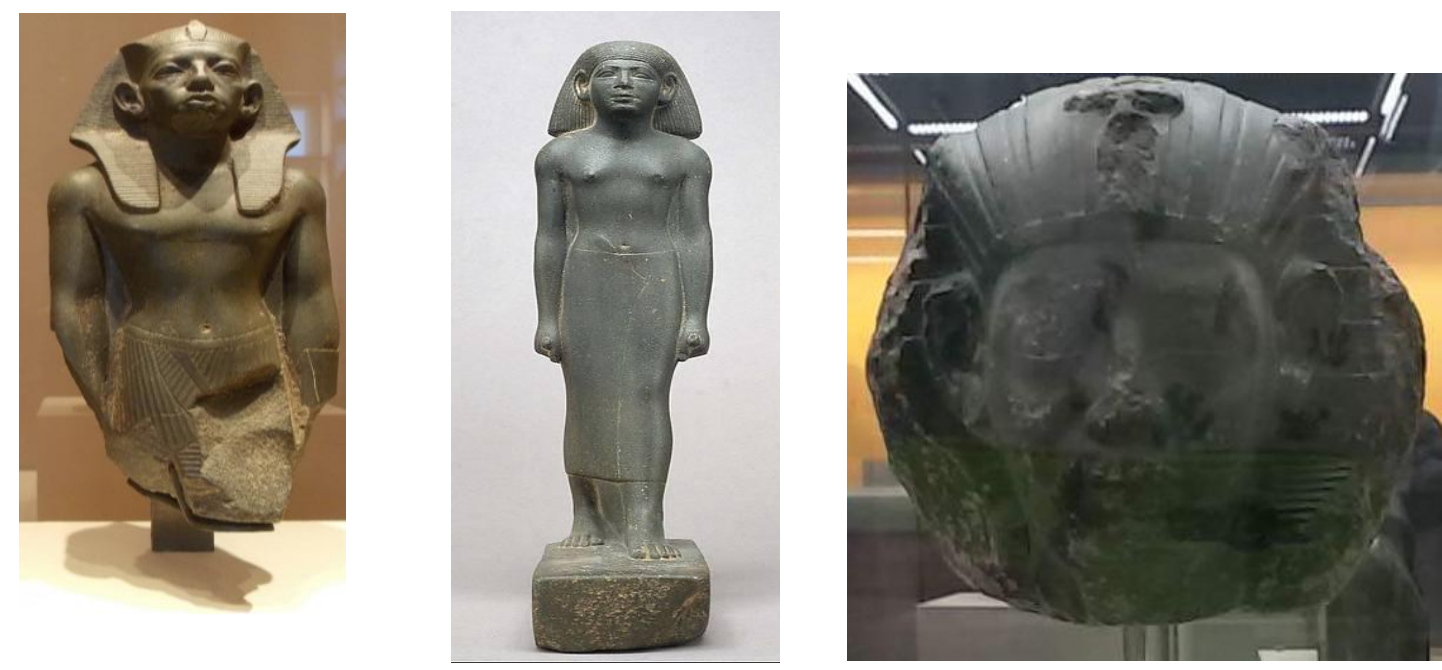
Statue of king Amenemhat III: Middle Kingdom $12^{\text {th }}$ Dynasty (1843 - 1798 BC.) (Louvre Museum, Paris, France - No. N 464).

Statuette of a striding man: Middle Kingdom (mid 12 ${ }^{\text {th }}$ Dynasty, ca. 1900-1850

B.C.) - (The Metropolitan Museum of Art - No. 07.228.180).

Head of a sphinx of Sesostris III / Amenemhat III: Second half of the $12^{\text {th }}$ Dynasty (1870

- 1786 BC) - (National Archaeological Museum of Naples, Italy - No. 387).

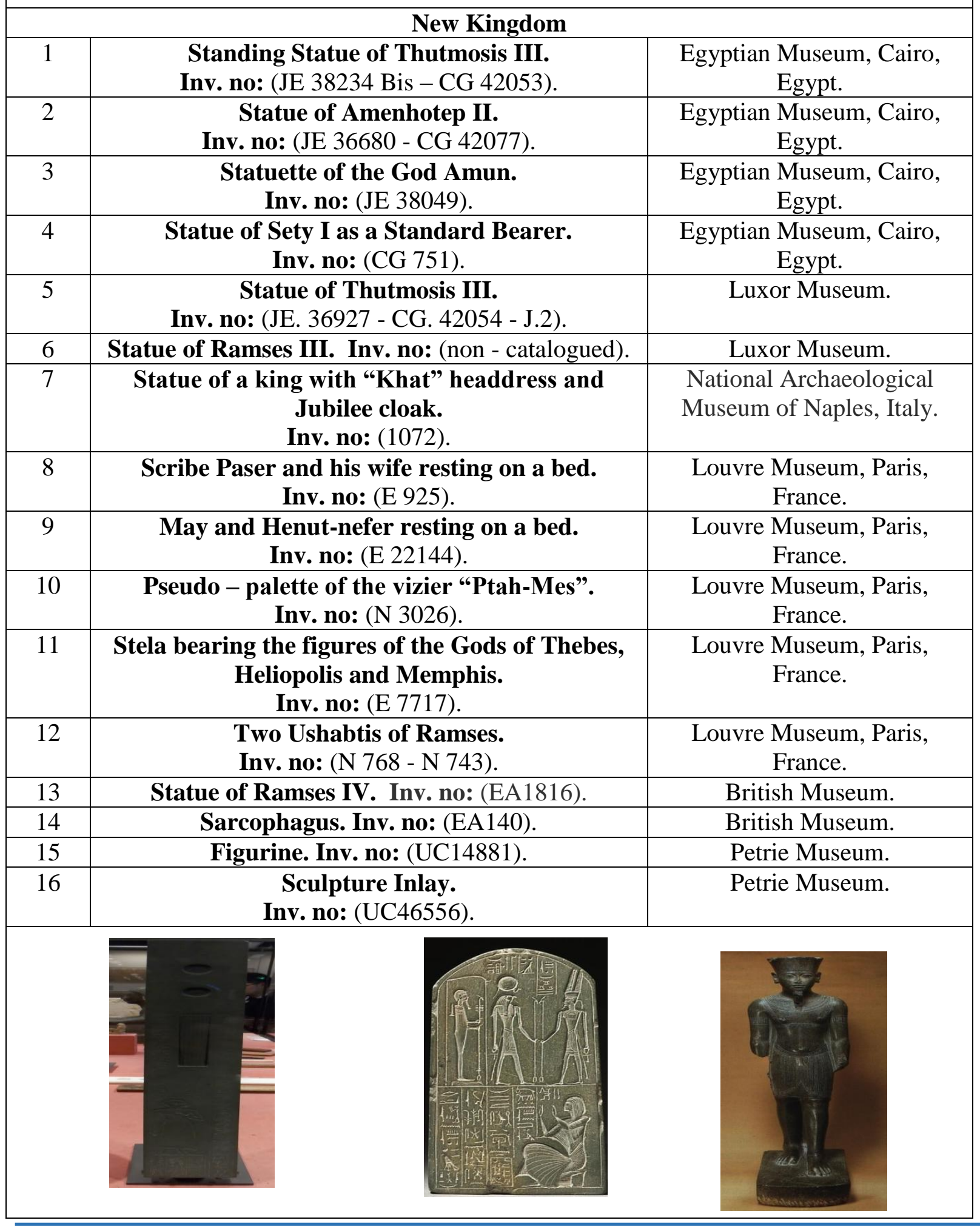


Pseudo - palette of the vizier "Ptah-Mes": New Kingdom, Reign of Thutmosis III (1479 - 1425 BC). (Louvre Museum, Paris, France - no. N 3026).

Stela bearing the figures of the Gods of Thebes, Heliopolis and Memphis: New Kingdom, Reign of Ramses II. (The Louvre Museum, Paris, France - no. E 7717).

Statuette of the god Amun: New Kingdom, End of the $18^{\text {th }}$ Dynasty, about 1320 BC (Egyptian Museum, Cairo, Egypt - Room 12 - JE 38049).

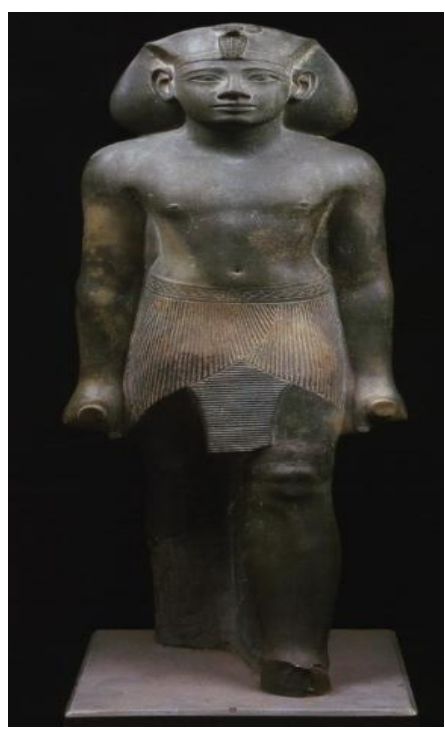

Statue of Amenhotep II: New Kingdom, 18th Dynasty, Reign of

Reign of Amenhotep II, (1439 - 1414 BC) - (Egyptian Museum, Cairo, Egypt - Room 12, JE 36680 - CG 42077).

\begin{tabular}{|c|c|c|}
\hline \multicolumn{3}{|c|}{ Third Intermediate Period - Late Period } \\
\hline 1 & $\begin{array}{c}\text { Cube statue of "Hor" son of "Ankh-khonsu". } \\
\text { Inv. no: (JE 37150). }\end{array}$ & $\begin{array}{l}\text { Egyptian Museum, Cairo, } \\
\text { Egypt. }\end{array}$ \\
\hline 2 & $\begin{array}{c}\text { Statue of Hathor and Psamtek. } \\
\text { Inv. no: }(\text { CG 784). }\end{array}$ & $\begin{array}{l}\text { Egyptian Museum, Cairo, } \\
\text { Egypt. }\end{array}$ \\
\hline 3 & $\begin{array}{c}\text { Statue of Osiris. } \\
\text { Inv. no: (CG 38358). }\end{array}$ & $\begin{array}{l}\text { Egyptian Museum, Cairo, } \\
\text { Egypt. }\end{array}$ \\
\hline 4 & $\begin{array}{c}\text { Statue of Isis. } \\
\text { Inv. no: (CG 38884). }\end{array}$ & $\begin{array}{l}\text { Egyptian Museum, Cairo, } \\
\text { Egypt. }\end{array}$ \\
\hline 5 & $\begin{array}{l}\text { Statue of Taweret. } \\
\text { Inv. no: (CG 39194). }\end{array}$ & $\begin{array}{l}\text { Egyptian Museum, Cairo, } \\
\text { Egypt. }\end{array}$ \\
\hline 6 & $\begin{array}{l}\text { Statue of the Vizier "Nespaqashuty". } \\
\text { Inv. no: (JE 36665). }\end{array}$ & $\begin{array}{l}\text { Egyptian Museum, Cairo, } \\
\text { Egypt. }\end{array}$ \\
\hline 7 & $\begin{array}{l}\text { Statue of "Ahmes" son of "Nespanebdjed". } \\
\text { Inv. no: (JE. 37075). }\end{array}$ & $\begin{array}{l}\text { Egyptian Museum, Cairo, } \\
\text { Egypt. }\end{array}$ \\
\hline 8 & Head of Osiris. Inv. no: (J. 143). & Luxor Museum. \\
\hline 9 & $\begin{array}{l}\text { Bust of a High Official. } \\
\text { Inv. no: (C. 3075). }\end{array}$ & $\begin{array}{l}\text { Egyptian Museum of Turin, } \\
\text { Italy. }\end{array}$ \\
\hline 10 & $\begin{array}{l}\text { Bust of a Male Statue. } \\
\text { Inv. no: (C. } 3078) \text {. }\end{array}$ & $\begin{array}{l}\text { Egyptian Museum of Turin, } \\
\text { Italy. }\end{array}$ \\
\hline 11 & Bust of a Private Statue. & Egyptian Museum of Turin, \\
\hline
\end{tabular}




\begin{tabular}{|c|c|c|}
\hline & Inv. no: (C. 1393). & Italy. \\
\hline 12 & $\begin{array}{c}\text { Lid of the Sarcophagus of "Ibi". } \\
\text { Inv. no: (C. 2202). }\end{array}$ & $\begin{array}{l}\text { Egyptian Museum of Turin, } \\
\text { Italy. }\end{array}$ \\
\hline 13 & $\begin{array}{l}\text { Sarcophagus of the vizier "Gem-en-ef-her-bak". } \\
\text { Inv. no: (C. 2201/1-2). }\end{array}$ & $\begin{array}{l}\text { Egyptian Museum of Turin, } \\
\text { Italy. }\end{array}$ \\
\hline 14 & $\begin{array}{c}\text { Statue presenting a shrine (Naophore) } \\
\text { of Royal Herald "Hor". } \\
\text { Inv. no: (C. 3026). }\end{array}$ & $\begin{array}{l}\text { Egyptian Museum of Turin, } \\
\text { Italy. }\end{array}$ \\
\hline 15 & $\begin{array}{l}\text { Inscribed Scarab. } \\
\text { Inv. no: (C. 5993). }\end{array}$ & $\begin{array}{l}\text { Egyptian Museum of Turin, } \\
\text { Italy. }\end{array}$ \\
\hline 16 & $\begin{array}{l}\text { Statue of Osiris. } \\
\text { Inv. no: (C. 30). }\end{array}$ & $\begin{array}{l}\text { Egyptian Museum of Turin, } \\
\text { Italy. }\end{array}$ \\
\hline 17 & $\begin{array}{c}\text { Head of a Royal Statue (Psmatik I). } \\
\text { Inv. no: }(\text { S. } 1225 / 2)\end{array}$ & $\begin{array}{l}\text { Egyptian Museum of Turin, } \\
\text { Italy. }\end{array}$ \\
\hline 18 & $\begin{array}{l}\text { Head of a king wearing a "Nemes" headdress. } \\
\text { Inv. no: (Unidentified). }\end{array}$ & $\begin{array}{l}\text { National Archaeological } \\
\text { Museum of Naples, Italy. }\end{array}$ \\
\hline 19 & $\begin{array}{c}\text { Portrait Head of an official. } \\
\text { Inv. no: (388). }\end{array}$ & $\begin{array}{l}\text { National Archaeological } \\
\text { Museum of Naples, Italy. }\end{array}$ \\
\hline 20 & $\begin{array}{l}\text { Torso of an accountant scribe of the temple of } \\
\text { Neith. } \\
\text { Inv. no: }(1067) \text {. }\end{array}$ & $\begin{array}{l}\text { National Archaeological } \\
\text { Museum of Naples, Italy. }\end{array}$ \\
\hline 21 & $\begin{array}{c}\text { A Fragment of a statue of "Shabaka". } \\
\text { Inv. no: (N 2541). }\end{array}$ & $\begin{array}{l}\text { Louvre Museum, Paris, } \\
\text { France. }\end{array}$ \\
\hline 22 & $\begin{array}{l}\text { Inscribed Fragment. } \\
\text { Inv. no: (N 520). }\end{array}$ & $\begin{array}{l}\text { Louvre Museum, Paris, } \\
\text { France. }\end{array}$ \\
\hline 23 & $\begin{array}{l}\text { Statue of a man dedicated to Horus. } \\
\text { Inv. no: (E 10709). }\end{array}$ & $\begin{array}{l}\text { Louvre Museum, Paris, } \\
\text { France. }\end{array}$ \\
\hline 24 & $\begin{array}{c}\text { Statue of a priest. } \\
\text { Inv. no: (E 10777). }\end{array}$ & $\begin{array}{l}\text { Louvre Museum, Paris, } \\
\text { France. }\end{array}$ \\
\hline 25 & $\begin{array}{l}\text { Psamtik presents an image of Osiris. } \\
\text { Inv. no: (E 9417). }\end{array}$ & $\begin{array}{l}\text { Louvre Museum, Paris, } \\
\text { France. }\end{array}$ \\
\hline 26 & $\begin{array}{c}\text { Selkis bearing Osiris. } \\
\text { Inv. no: (E 20060). }\end{array}$ & $\begin{array}{l}\text { Louvre Museum, Paris, } \\
\text { France. }\end{array}$ \\
\hline 27 & $\begin{array}{c}\text { Two Statues of Osiris. } \\
\text { Inv. no: (N } 3952 \text { - E 9418). }\end{array}$ & $\begin{array}{l}\text { Louvre Museum, Paris, } \\
\text { France. }\end{array}$ \\
\hline 28 & $\begin{array}{l}\text { Statuette of Isis breastfeeding Horus. } \\
\text { Inv. no: (N 3991). }\end{array}$ & $\begin{array}{l}\text { Louvre Museum, Paris, } \\
\text { France. }\end{array}$ \\
\hline 29 & $\begin{array}{l}\text { Statue of "Ankh-ef-en-sekhmet", Tutor of the } \\
\text { king. Inv. no: (E 25459). }\end{array}$ & $\begin{array}{l}\text { Louvre Museum, Paris, } \\
\text { France. }\end{array}$ \\
\hline 30 & $\begin{array}{l}\text { Chief of the court "Iahmes - sa - Neith". } \\
\text { Inv. no: (E 25390 - E 25475). }\end{array}$ & $\begin{array}{l}\text { Louvre Museum, Paris, } \\
\text { France. }\end{array}$ \\
\hline 31 & $\begin{array}{l}\text { Statue of a man presenting an effigy of Osiris. } \\
\text { Inv. no: (E 4299). }\end{array}$ & $\begin{array}{l}\text { Louvre Museum, Paris, } \\
\text { France. }\end{array}$ \\
\hline 32 & $\begin{array}{l}\text { Lid of the sarcophagus of “Djed - Hor". } \\
\text { Inv. no: (D 9). }\end{array}$ & $\begin{array}{l}\text { Louvre Museum, Paris, } \\
\text { France. }\end{array}$ \\
\hline 33 & $\begin{array}{l}\text { Statue of "Horoudja". } \\
\text { Inv. no: (N 2452). }\end{array}$ & $\begin{array}{l}\text { Louvre Museum, Paris, } \\
\text { France. }\end{array}$ \\
\hline 34 & $\begin{array}{l}\text { Statue of the steward "Hekat - ef - nakht" } \\
\text { presenting Osiris. Inv. no: (E 25499). }\end{array}$ & $\begin{array}{l}\text { Louvre Museum, Paris, } \\
\text { France. }\end{array}$ \\
\hline
\end{tabular}




\begin{tabular}{|c|c|c|}
\hline 35 & $\begin{array}{l}\text { Head of Osiris. } \\
\text { Inv. no: (E 10706). }\end{array}$ & $\begin{array}{l}\text { Louvre Museum, Paris, } \\
\text { France. }\end{array}$ \\
\hline 36 & $\begin{array}{l}\text { Block statue of the priest "Imnemiptditipy". } \\
\text { Inv. no: (E 10366). }\end{array}$ & $\begin{array}{l}\text { Louvre Museum, Paris, } \\
\text { France. }\end{array}$ \\
\hline 37 & $\begin{array}{c}\text { Sarcophagus of "Tenet - Hapy". } \\
\text { Inv. no: (D 39). }\end{array}$ & $\begin{array}{l}\text { Louvre Museum, Paris, } \\
\text { France. }\end{array}$ \\
\hline 38 & $\begin{array}{l}\text { Head of a shaved man. } \\
\text { Inv. no: (E 25577). }\end{array}$ & $\begin{array}{l}\text { Louvre Museum, Paris, } \\
\text { France. }\end{array}$ \\
\hline 39 & $\begin{array}{l}\text { Torso of king Nectanebo I. } \\
\text { Inv. no: (E 25492). }\end{array}$ & $\begin{array}{l}\text { Louvre Museum, Paris, } \\
\text { France. }\end{array}$ \\
\hline 40 & $\begin{array}{l}\text { Statue of "Shepsesirdis". } \\
\text { Inv. no: (E 18967). }\end{array}$ & $\begin{array}{l}\text { Louvre Museum, Paris, } \\
\text { France. }\end{array}$ \\
\hline 41 & $\begin{array}{l}\text { Head of one of the believers of "Ptah". } \\
\text { Inv. no: (E 10710). }\end{array}$ & $\begin{array}{l}\text { Louvre Museum, Paris, } \\
\text { France. }\end{array}$ \\
\hline 42 & $\begin{array}{l}\text { Fragment of a votive monument. } \\
\text { Inv. no: (E 32648). }\end{array}$ & $\begin{array}{l}\text { Louvre Museum, Paris, } \\
\text { France. }\end{array}$ \\
\hline 43 & $\begin{array}{c}\text { Heart Scarab. } \\
\text { Inv. no: }(08.480 .168) .\end{array}$ & $\begin{array}{l}\text { Brooklyn Museum, New } \\
\text { York. }\end{array}$ \\
\hline 44 & $\begin{array}{l}\text { Fragment of the Feet and Base of a Statue. } \\
\text { Inv. no: }(79.31) \text {. }\end{array}$ & $\begin{array}{l}\text { Brooklyn Museum, New } \\
\text { York. }\end{array}$ \\
\hline 45 & Head of King Amasis. Inv. no: (2007.81). & Metropolitan Museum of Art. \\
\hline 46 & $\begin{array}{l}\text { Naophorous Block Statue of a Governor of } \\
\text { Sais, Psamtik (Seneb). Inv. no: (1982.318). }\end{array}$ & Metropolitan Museum of Art. \\
\hline 47 & $\begin{array}{c}\text { Sarcophagus of "Harkhebit". } \\
\text { Inv. no: }(07.229 .1 \mathrm{a}, \mathrm{b}) . \\
\end{array}$ & Metropolitan Museum of Art. \\
\hline 48 & $\begin{array}{l}\text { Statue of "Harbes" called "Psamtik-Nefer", } \\
\text { son of "Ptah-Hotep". Inv. no: (19.2.2). }\end{array}$ & Metropolitan Museum of Art. \\
\hline 49 & $\begin{array}{l}\text { Kneeling statue of "Amen-em-opet-em-hat". } \\
\text { Inv. no: }(24.2 .2) \text {. }\end{array}$ & Metropolitan Museum of Art. \\
\hline 50 & $\begin{array}{c}\text { Antelope Head. } \\
\text { Inv. no: }(1992.55) .\end{array}$ & Metropolitan Museum of Art. \\
\hline 51 & $\begin{array}{l}\text { Man, holding a Shrine Containing an Image of } \\
\text { Osiris. Inv. no: }(25.2 .10) \text {. }\end{array}$ & Metropolitan Museum of Art. \\
\hline 52 & $\begin{array}{c}\text { Head of a Male Priest. } \\
\text { Inv. no: }(49.101 .2)\end{array}$ & Metropolitan Museum of Art. \\
\hline 53 & $\begin{array}{l}\text { Bust of an anonymous scribe. } \\
\text { Inv. no: }(25.2 .1)\end{array}$ & Metropolitan Museum of Art. \\
\hline 54 & $\begin{array}{l}\text { Torso of a High General. } \\
\text { Inv. no: }(1996.91) \text {. }\end{array}$ & Metropolitan Museum of Art. \\
\hline 55 & $\begin{array}{l}\text { Magical Stela. } \\
\text { Inv. no: }(50.85) .\end{array}$ & Metropolitan Museum of Art. \\
\hline 56 & $\begin{array}{c}\text { God Horus Protecting King Nectanebo II. } \\
\text { Inv. no: }(34.2 .1) \text {. }\end{array}$ & Metropolitan Museum of Art. \\
\hline 57 & The Shabako Stone. Inv. no: (EA498). & British Museum. \\
\hline 58 & Dish. Inv. no: (EA23831). & British Museum. \\
\hline 59 & Vessel Model. Inv. no: (EA18559). & British Museum. \\
\hline 60 & Plaque. (EA27571). & British Museum. \\
\hline 61 & Broken Head of a Statue. Inv. no: (EA97). & British Museum. \\
\hline 62 & Architectural Element of Nectanebo I. & British Museum. \\
\hline
\end{tabular}




\begin{tabular}{|c|c|c|}
\hline & Inv. no: (EA22). & \\
\hline 63 & $\begin{array}{c}\text { Bath-tub / Sarcophagus / Religious/ Ritual } \\
\text { Vessel. Inv. no: (EA10). }\end{array}$ & British Museum. \\
\hline 64 & $\begin{array}{c}\text { Greywacke Obelisks of Nectanebo II. } \\
\text { Inv. no: (EA 523 - EA 524). }\end{array}$ & British Museum. \\
\hline 65 & $\begin{array}{c}\text { Statue of Osiris. } \\
\text { Inv. no: (2000.973). }\end{array}$ & Boston Museum of Fine Arts. \\
\hline 66 & $\begin{array}{c}\text { Statue of Vizier "Bakenrenef”. } \\
\text { Inv. no: (1970.495). }\end{array}$ & Boston Museum of Fine Arts. \\
\hline 67 & $\begin{array}{c}\text { Head of “Ankh-khonsu". } \\
\text { Inv. no: (04.1841). }\end{array}$ & Boston Museum of Fine Arts. \\
\hline 68 & $\begin{array}{c}\text { Head of a Priest (The Boston Green Head). } \\
\text { Inv. no: (04.1749). }\end{array}$ & Petrie Museum. \\
\hline 69 & Grain rubber, Polisher. Inv. no: (UC29898f). & Petrie Museum. \\
\hline 70 & Scarab. Inv. no: (UC29867). & Petrie Museum. \\
\hline 71 & Amulet. Inv. no: (UC2413). & Petrie Museum. \\
\hline 72 & Broken bust of Statue. Inv. no: (UC14634). & Petrie Museum. \\
\hline 73 & Amulet. Inv. no: (UC52074). & \\
\hline 74 & Figurine. Inv. no: (UC42553). & \\
\hline
\end{tabular}
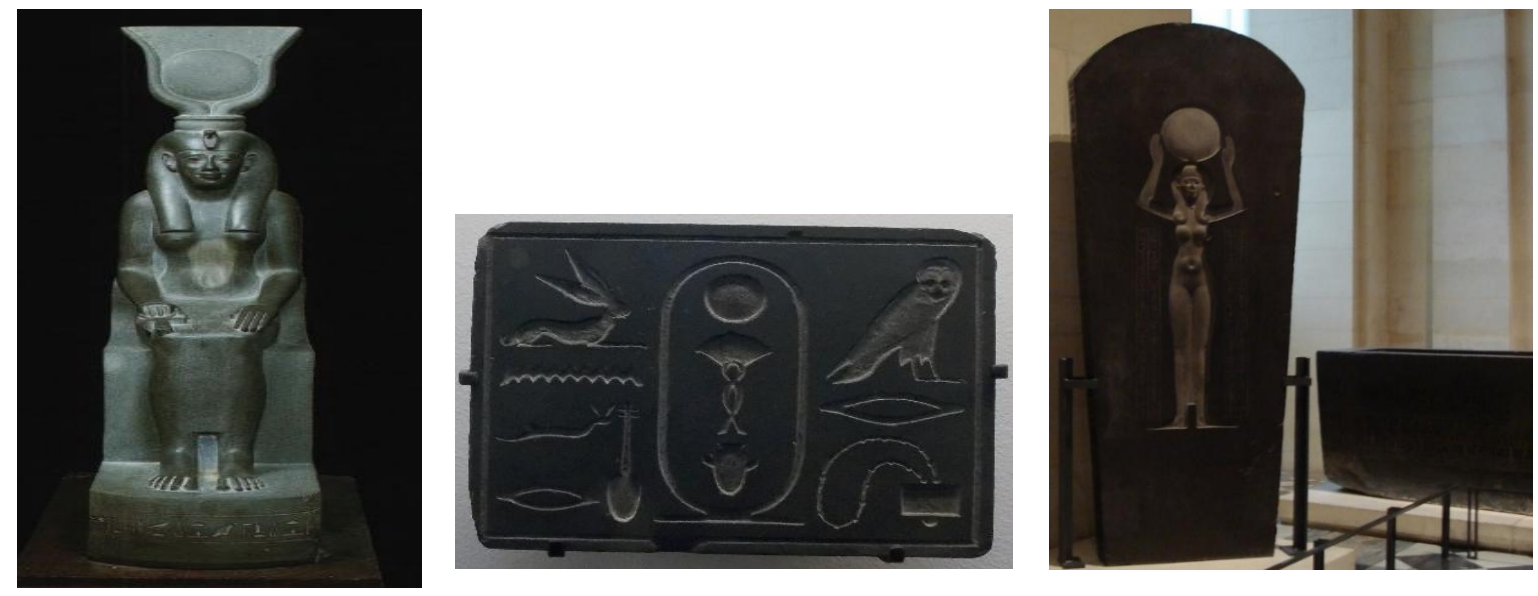

Statue of Isis: End of the $26^{\text {th }}$ Dynasty (first half of the $6^{\text {th }}$ century BC), (Egyptian Museum, Cairo, Egypt, Room 24 - CG 38884).

Inscribed fragment: $26^{\text {th }}$ Dynasty $(664-525$ BC.) - (Louvre Museum, Paris, France - No. N 520).

Lid of the sarcophagus of Djed - Hor: IV century BC. (Louvre Museum, Paris, France -

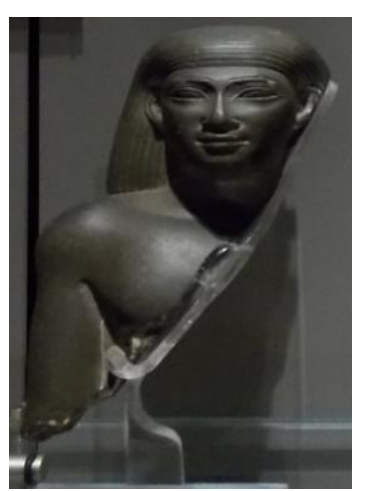
No. D9).
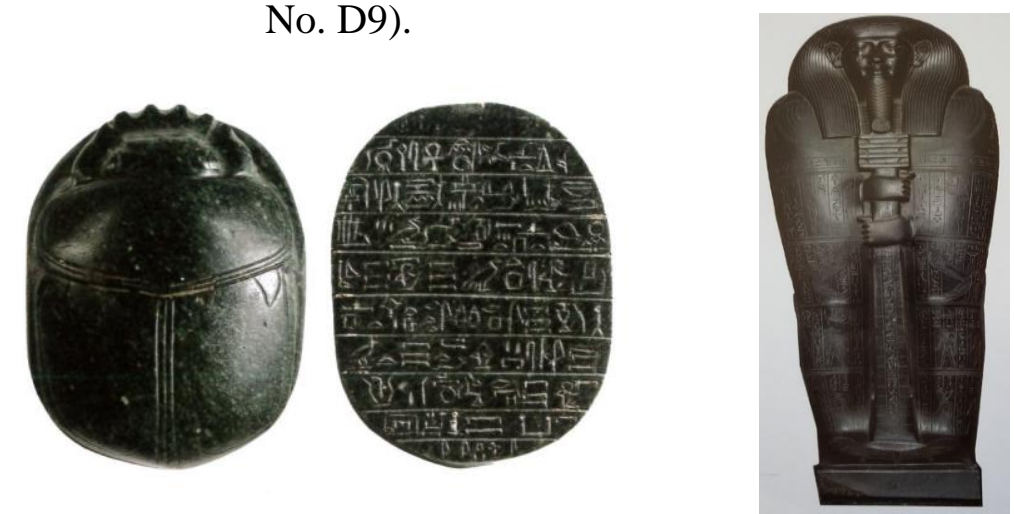
Bust of a private statue: Late Period, $26^{\text {th }}$ Dynasty, reign of Psamtek I, II, III (664 - 525 BC.).

(The Egyptian Museum of Turin, Italy, no. C. 1393).

Inscribed Scarab: Third Intermediate Period (1076 - 722 B.C.),

(The Egyptian Museum of Turin, Italy, no. C. 5993).

lid of the Sarcophagus of Ibi: Late Period, $26^{\text {th }}$ Dynasty, reign of Psmatek I (664 - 610

BC), (The Egyptian Museum of Turin, Italy, no. C. 2202).

\begin{tabular}{|c|c|c|}
\hline \multicolumn{3}{|c|}{ Ptolemaic Period } \\
\hline 1 & $\begin{array}{l}\text { Stela of Horus on crocodiles. } \\
\text { Inv. no: (CG 9401). }\end{array}$ & $\begin{array}{l}\text { Egyptian Museum, Cairo, } \\
\text { Egypt. }\end{array}$ \\
\hline 2 & $\begin{array}{l}\text { Head of Ptolemy II. } \\
\text { Inv. no: (C. 1399). }\end{array}$ & $\begin{array}{l}\text { Egyptian Museum of Turin, } \\
\text { Italy. }\end{array}$ \\
\hline 3 & $\begin{array}{l}\text { Theophorous Statue. } \\
\text { Inv. no: (Unidentified). }\end{array}$ & $\begin{array}{l}\text { National Archaeological } \\
\text { Museum of Naples, Italy. }\end{array}$ \\
\hline 4 & $\begin{array}{c}\text { Sarcophagus of "Ank-hapy", } \\
\text { The priest of king Sneferu and the god Ptah. } \\
\text { Inv. no: (D 13). }\end{array}$ & $\begin{array}{l}\text { Louvre Museum, Paris, } \\
\text { France. }\end{array}$ \\
\hline 5 & $\begin{array}{l}\text { Sarcophagus of the Priest "Ankh - mr - wr". } \\
\text { Inv. no: (D 7). }\end{array}$ & $\begin{array}{l}\text { Louvre Museum, Paris, } \\
\text { France. }\end{array}$ \\
\hline 6 & $\begin{array}{l}\text { A Ptolemaic king offering Maat to Amun - Ra, } \\
\text { Mut and Khonsou. Inv. no: (C 121). }\end{array}$ & $\begin{array}{l}\text { Louvre Museum, Paris, } \\
\text { France. }\end{array}$ \\
\hline 7 & $\begin{array}{c}\text { Fragment of a Naos inscribed with a Royal } \\
\text { decree. Inv. no: (N } 274-\text { C 123). }\end{array}$ & $\begin{array}{l}\text { Louvre Museum, Paris, } \\
\text { France. }\end{array}$ \\
\hline 8 & $\begin{array}{l}\text { Sarcophagus of the Greek - Egyptian Tisicrates. } \\
\text { Inv. no: (D 40). }\end{array}$ & $\begin{array}{l}\text { Louvre Museum, Paris, } \\
\text { France. }\end{array}$ \\
\hline 9 & $\begin{array}{l}\text { Statue of Imhotep dedicated by "Wah - Ib - Re". } \\
\text { Inv. no: (N 4541). }\end{array}$ & $\begin{array}{l}\text { Louvre Museum, Paris, } \\
\text { France. }\end{array}$ \\
\hline 10 & $\begin{array}{l}\text { Broken Statue of a Ptolemaic Prince. } \\
\text { Inv. no: }(54.117) \text {. }\end{array}$ & $\begin{array}{l}\text { Brooklyn Museum, New } \\
\text { York. }\end{array}$ \\
\hline 11 & $\begin{array}{l}\text { Feet from statue of Musician of Amun } \\
\text { Tasheritkhonsu. Inv. no: }(55.51) .\end{array}$ & Metropolitan Museum of Art. \\
\hline 12 & $\begin{array}{c}\text { Face attributed to Ptolemy II Philadelphos or a } \\
\text { contemporary. } \\
\text { Inv. no: }(12.187 .31)\end{array}$ & Metropolitan Museum of Art. \\
\hline 13 & $\begin{array}{c}\text { Portrait Head. } \\
\text { Inv. no: }(1926,0415.15) .\end{array}$ & British Museum. \\
\hline
\end{tabular}
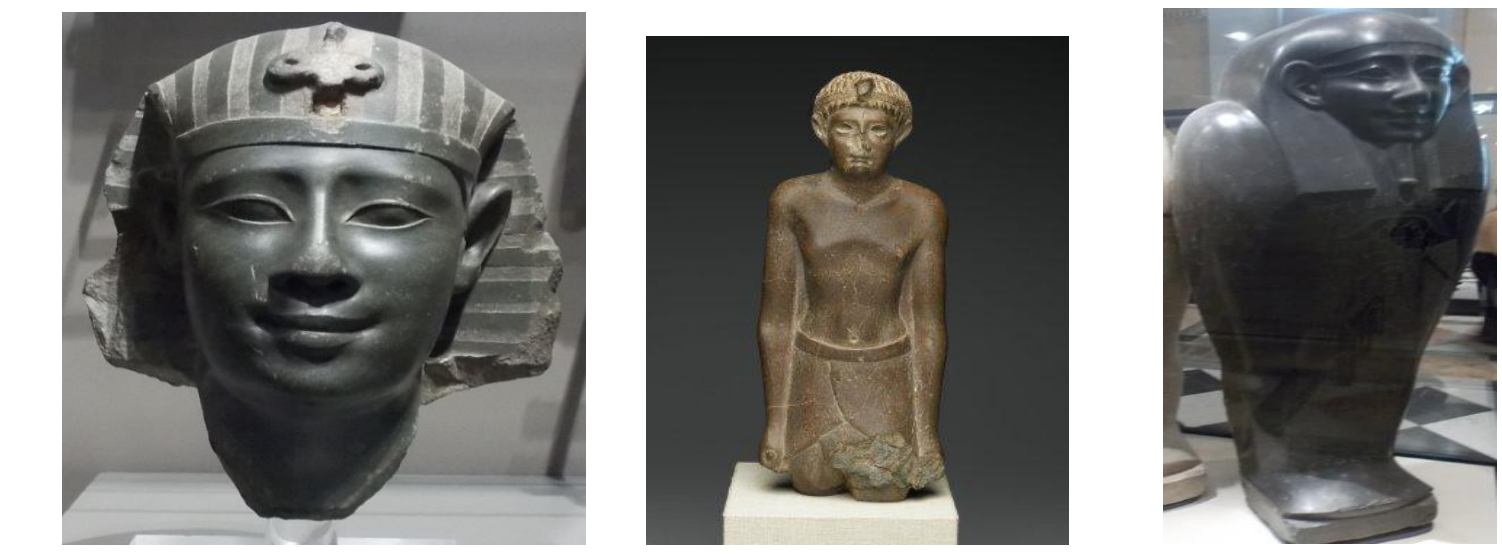
Head of Ptolemy II: Ptolemaic Period (284 - 246 BC.) - (Egyptian museum, Turin, No. C. 1399).

Broken Statue of a Ptolemaic Prince: Late Ptolemaic Period (50-30 B.C.) - (The Brooklyn Museum, New York, no. 54.117).

Sarcophagus of the Priest (Ankh $-\mathbf{m r}-\mathbf{w r}): 3^{\text {rd }}-2^{\text {nd }}$ century BC. (Ptolemaic Period) (The Louvre Museum, Paris, France - no. D 7).

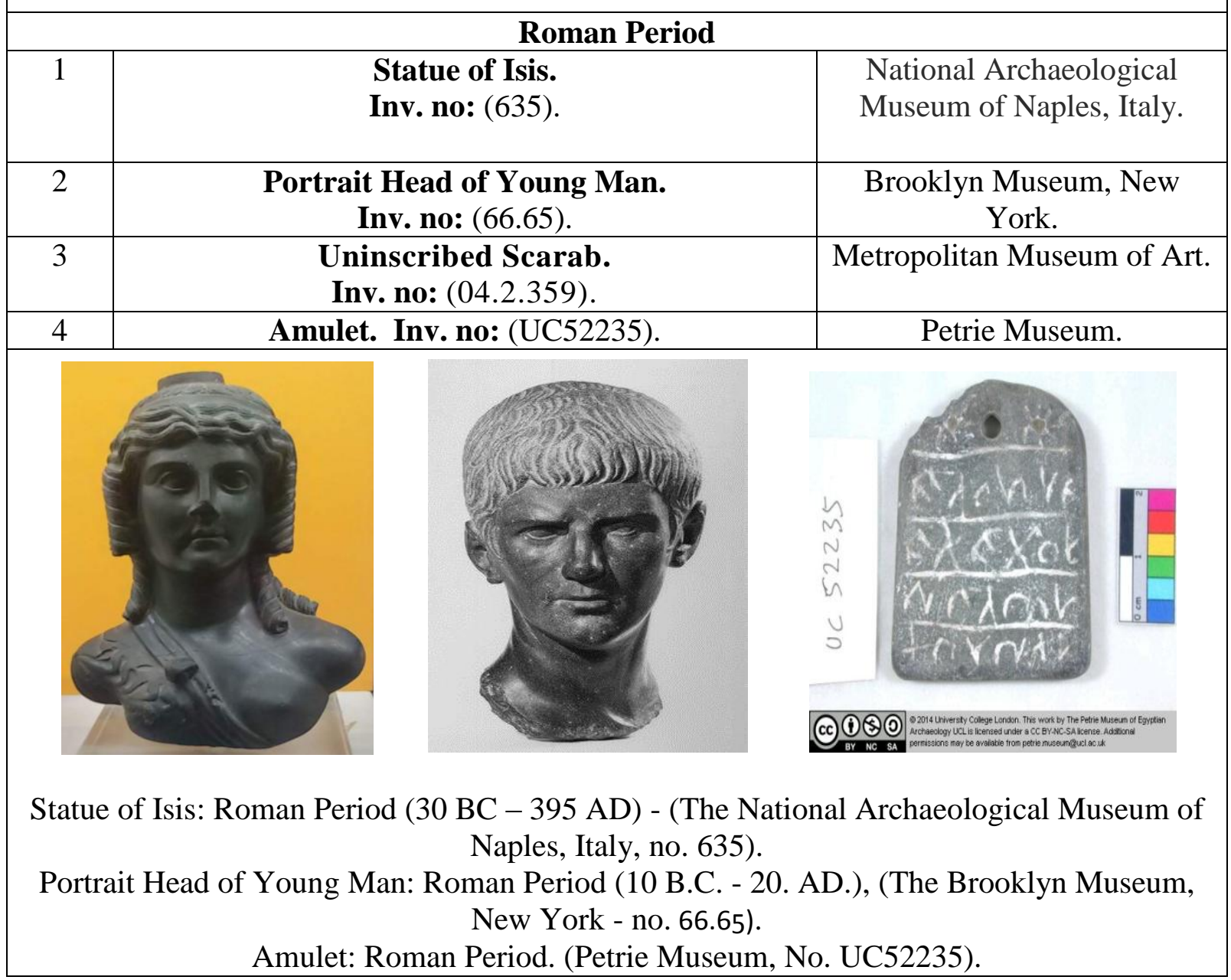

\section{Conclusion}

- The catalogue of greywacke objects preserved in several museums around the world prepared by the researcher resulted a total of 181 well-dated objects related to the quarrying and use of greywacke through the different historical phases. 


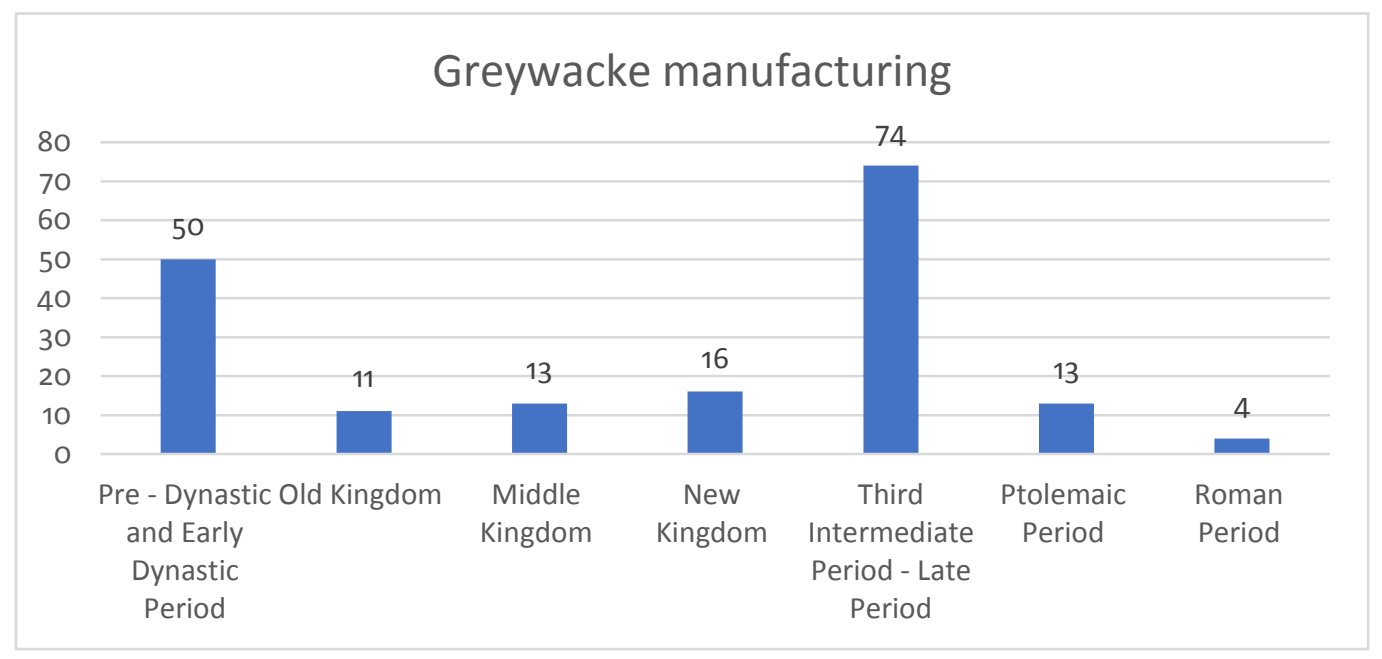

- Bekhen stone represents a variety of uses such as:

I. Small objects (vessels, palettes, bracelets, beads).

II. Large objects (statues, coffins, sarcophagi, naoi) usually found in burial and votive contexts.

III. Tools (chisels and wedges) primarily connected with the quarrying process.

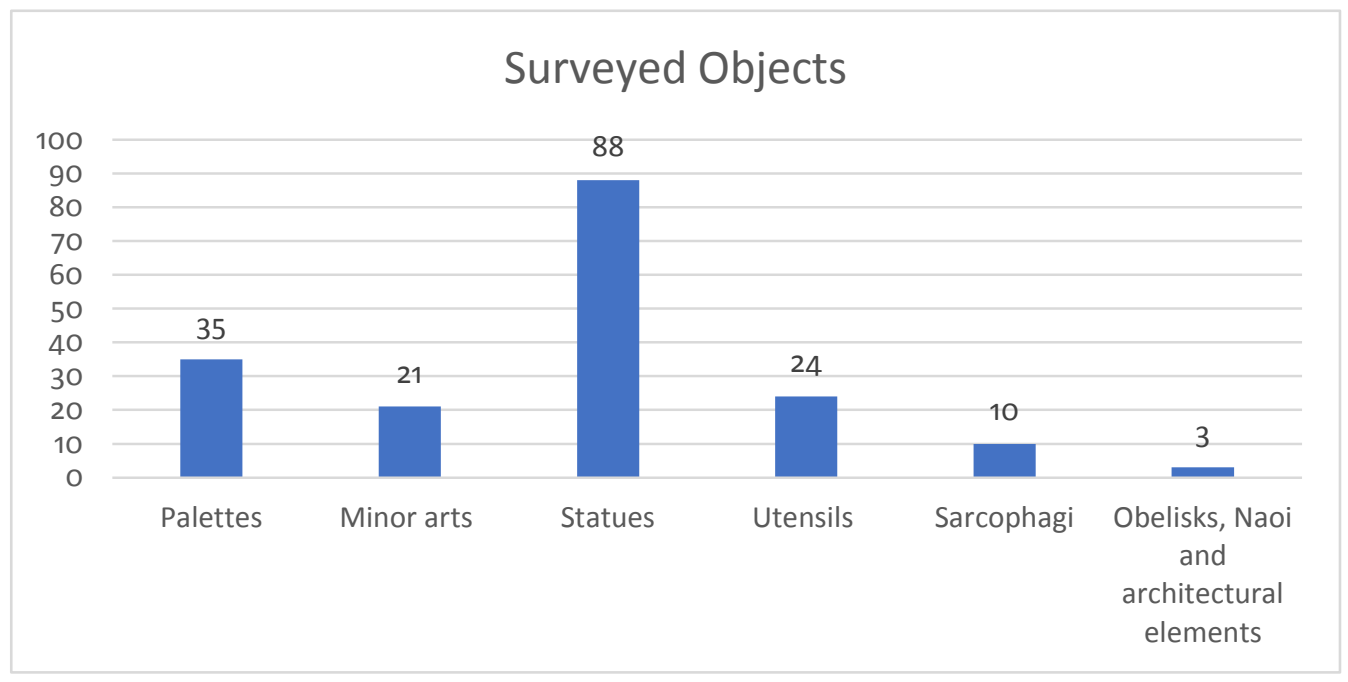

\section{This survey indicated that:}

- The pre - dynastic and early dynastic period witnessed intensive quarrying activities of greywacke reflected in a huge number of sculptures, mainly palettes. This should have been due to the primitive tools and quarrying techniques that helped in obtaining small dimensions of quarried stones in this early period.

- The mass quarrying activities occurred during the Late Period (Third Intermediate Period) of which the manufactured greywacke objects reached 74 pieces of mainly statuary (Standing statues - Cube statues - Heads - Busts and torsos), sarcophagi, magical stelae, obelisks, amulets and figurines.

- The low quarrying and consequently sculpture rate is applied on the Roman Period (4 pieces), most probably due to the fear of the "Blemmy's" tribes mentioned in the Roman 
resources, the unsafe situation in the Eastern Desert during this period or the interest of extracting and sculpting other types of stones such as the porphyrites of Mons Claudianus.

- The period extending from the Old Kingdom till the New Kingdom then the Ptolemaic Period witnessed a stable medium rate of use and interest towards the greywacke.

- Wadi Hammamat quarries were inherently centers of social interaction, as well as places where technology could be transmitted and maintained across generations. The instances where rock engravings are associated with quarries can provide additional insights into the ways in which production landscapes were socialized overtime. As a social activity, engraving on rocks might not only define access and control of specific landscapes and resources, but also represents how visual "art" became an enduring medium of expression related to shared experience and group identity that linked the past with the present, as well as the future.

\section{References}

\footnotetext{
${ }^{1}$ Lecturer of the Ancient Egyptian Language and Civilization in The High Institute of Tourism, Hotel Management and Restoration, Abu Qir, Alexandria, Egypt. This article is a survey executed during the researcher's PHD thesis work in the Università degli Studi di Padova, Italy.

Ahmed Othman, Evaluating the Cultural Heritage and landscape of Quseir - Qift Road: with a special focus on the gold mines and greywacke quarries, (PHD Thesis, Università degli studi di Padova, 2017).

2 Elizabeth Bloxam, “A Place Full of Whispers": Socializing the Quarry Landscape of the Wadi Hammamat", CAJ 25, (2015), 789 - 814; Elizabeth Bloxam, et al. "Investigating the Predynastic origins of greywacke working in the Wadi Hammamat", Archeonil 24, (2014), 11 - 30.

3 Alfred Lucas and Alan Rowe, "The Ancient Egyptian Bekhen Stone", ASAE 38, (1938), 127 - 156.

4 WB, I, 471; James A. Harrell, and V. Max Brown. "The Oldest Surviving Topographical Map from Ancient Egypt", JARCE XXIX, (1992), 81-105; G. Andrew, "The Greywackes of the Eastern Desert of Egypt", Bulletin de l'Institut d'Egypt, Tome XXI, (Le Caire, 1939), 153 - 190.

${ }^{5}$ LÄ II, col. 894; Wb, II, 398.

${ }^{6}$ Charles Boreux. Guide - Catalogue Sommaire, Dept. des Antiquites Egyptiennes, I, (1932), 149 - 150, C. 44.

${ }^{7}$ Jean Couyat, and Pierre Montet. Les Inscriptions Hiéroglyphiques et Hiératiques du Ouâdi Hammâmât, (Le Caire, 1912), 49, No. 47.

${ }^{8}$ J. Couyat, and P. Montet. Les Inscriptions Hiéroglyphiques, 76, No. 108.

9 J. Couyat, and P. Montet. Les Inscriptions Hiéroglyphiques, No. 48; Henri Gauthier. Dictionnaire des Noms Géographiques Contenus dans les Textes Hiéroglyphiques, I, (Le Caire, 1923), 148.
}

${ }^{10}$ A. Lucas, and A. Rowe, "The Ancient Egyptian Bekhen Stone", 133, text (F); James Henri Breasted. Ancient Records of Egypt, III, (Chicago, 1908), 99 - 101.

${ }^{11}$ J. Couyat, and P. Montet. Les Inscriptions Hiéroglyphiques, 111, No. 238.

${ }^{12}$ Alexandre Varille, "Quelques données nouvelles sur la pierre bekhen des anciens Égyptiens", BIFAO 34, 96 - 98, no. 5 .

${ }^{13}$ Adolf Erman, Life in Ancient Egypt, (London, 1894), 446; A. Lucas, and A. Rowe, "The Ancient Egyptian Bekhen Stone", 134 - 135, fig. 12.

${ }^{14}$ J. Couyat, and P. Montet. Les Inscriptions Hiéroglyphiques, 112, No. 240; H. Gauthier. Dictionnaire des Noms Géographiques, VI, 24.

${ }^{15}$ J. Couyat, and P. Montet. Les Inscriptions Hiéroglyphiques, 34, No. 12; A. Erman, Life in Ancient Egypt, $472-$ 475. 
${ }^{16}$ Referred to as of uncertain meaning in A. Lucas, and A. Rowe, "The Ancient Egyptian Bekhen Stone", 136, footnote, 4.

${ }^{17}$ J. Couyat, and P. Montet. Les Inscriptions Hiéroglyphiques, 123, No. 232.

${ }^{18}$ William M. Flinders Petrie, A Season in Egypt, (London, 1888), 26, pl. XXI, Fig. 5.

19 A. Varille, "Quelques données nouvelles", 98, no. 6.

${ }^{20}$ A. Varille, "Quelques données nouvelles", 94 - 95, no. 1.

${ }^{21}$ A. Varille, "Quelques données nouvelles”, 94 - 100, no. C.; Giovanni Kminek - Szedlo, Catalogo di Antichità Egizia del Museo Civico di Bologna, (Torino, 1895), 165 - 166, No. 1870.

${ }^{22}$ George Long, The Egyptian antiquities in the British Museum, I. (London, 1846), 50, 324 - 328; Harry Reginald Hall, Introductory Guide to the Egyptian Collections in the British Museum, (London, 1930), 395, fig. 218 ; A. Varille, "Quelques données nouvelles", 95; For further readings cf, Labib Habachi, The obelisks of Egypt: skyscrapers, (Scribner: New York, 1977).

${ }^{23}$ William M. Flinder Petrie, Koptos, (London, 1896), 21; A. Varille, “Quelques données nouvelles”, 99.

${ }^{24}$ A. Lucas, and A. Rowe, "The Ancient Egyptian Bekhen Stone", 143, Text (R).

25 August Mariette, Denderah, Vol. IV, (Paris, 1873), pl. XXXV, line 14.

${ }^{26}$ A. Lucas, and A. Rowe, "The Ancient Egyptian Bekhen Stone", 144 - 146, Text (T); Heinrich Brugsch, Die biblischen sieben Jahre der hungersnoth, (Leipzig, 1891), pls. XIV, XV.; Jacques De Morgan, et al. Catalogues des monuments et inscriptions de L'Egypte, Serie I, Vol. I, 1894, 79 - 82.

${ }^{27}$ J. A. Harrell, V. M. Brown, and L. Lazzarini, "Breccia Verde Antica: Sources, Petrology and Ancient Uses", ASMOSIA VI, June 2000, (Venice, 2002), 209.

${ }^{28}$ Rolf Gundlach, "Wadi Hammamat", in L̈̈, VI, (Wiesbaden), 1986, col. 1099 - 1113.

${ }^{29}$ J. A. Harrell, V. M. Brown, and L. Lazzarini, "Breccia Verde Antica", 210.

${ }^{30}$ J. A. Harrell, V. M. Brown, and L. Lazzarini, "Breccia Verde Antica", 210.

${ }^{31}$ Georges Goyon, Nouvelles inscriptions rupestres du Wadi Hammamat, (Paris, 1957), 337 - 392, fig. 14.

${ }^{32}$ J. A. Harrell, V. M. Brown, and L. Lazzarini, "Breccia Verde Antica", 210.

${ }^{33}$ J. A. Harrell, V. M. Brown, and L. Lazzarini, "Breccia Verde Antica", 211 - 213; for more about Hammamat greywacke, cf, R. Grothaus, D. Eppler, and R. Ehrlich. "Depositional Environment and Structural Implications of the Hammamat Formation", Annals of the Egyptian Geological Survey, Vol. 9, (Egypt, 1979), 456 - 590.

\section{$\underline{\text { Catalogue web sites }}$}

$\underline{\text { http://petriecat.museums.ucl.ac.uk }}$

https://www.brooklynmuseum.org/opencollection/objects

http://www.metmuseum.org/art/collection

http://www.mfa.org/collections/object

http://www.britishmuseum.org/research/collection_online 